Linköping University medical dissertations

No. 1544

\title{
Studies on interfaces \\ between primary and \\ secondary hemostasis
}
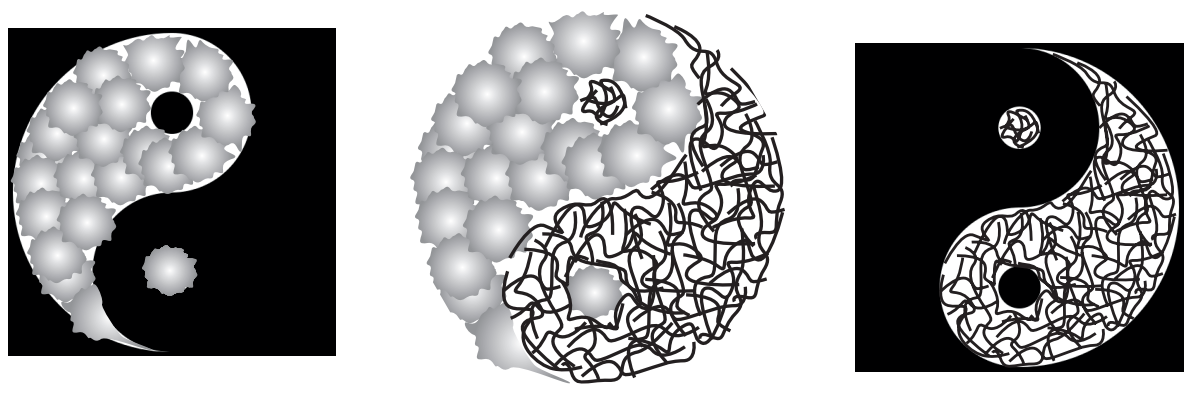

Niklas Boknäs

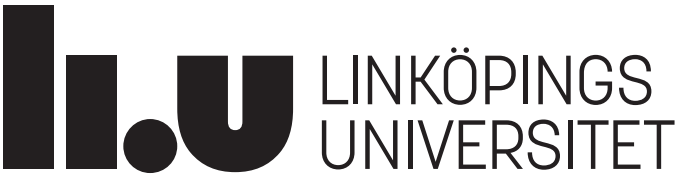


Department of Clinical and Experimental Medicine

(c) Niklas Boknäs 2016

ISBN: 978-91-7685-663-5

ISSN: 0345-0082

Printed in Sweden by LiU-Tryck. Linköping 2016 
Till Ellen, Elis och Martha 


\section{Abstract}

Our conceptual understanding of hemostasis is still heavily influenced by outdated experimental models wherein the hemostatic activity of platelets and coagulation factors are understood and studied in isolation. Although perhaps convenient for researchers and clinicians, this reductionist view is negated by an ever increasing body of evidence pointing towards an intimate relationship between the two phases of hemostasis, marked by strong interdependence. In this thesis, I have focused on factual and proposed interfaces between primary and secondary hemostasis, and on how these interfaces can be studied.

In my first project, we zoomed in on the mechanisms behind the wellknown phenomenon of thrombin-induced platelet activation, an important event linking secondary to primary hemostasis. In our study, we examined how thrombin makes use of certain domains for high-affinity binding to substrates, called exosite I and II, to activate platelets via PAR4. We show that thrombin-induced platelet activation via PAR4 is critically dependent on exosite II, and that blockage of exosite II with different substances virtually eliminates PAR4 activation. Apart from providing new insights into the mechanisms by which thrombin activates PAR4, these results expand our knowledge of the antithrombotic actions of various endogenous proteins such as members of the serpin superfamily, which inhibit interactions with exosite II. Additionally, we show that inhibition of exosite II could be a feasible pharmacological strategy for achieving selective blockade of PAR4.

In my second project, we examined the controversial issue of whether platelets can initiate the coagulation cascade by means of contact activation, a hypothesis which, if true, could provide a direct link between primary and secondary hemostasis. In contrast to previous results, our findings falsify this hypothesis, and show that some of the erroneous conclusions drawn from earlier studies can be explained by inappropriate experimental models unsuitable for the study of platelet-coagulation interfaces.

My third project comprised an assessment of the methodological difficulties encountered when trying to measure the ability of platelets to initiate secondary hemostasis by the release of microparticles expressing tissue factor. Our study shows that the functional assays available for this purpose are highly susceptible to error caused by artificial contact activation. These results could help to improve the methodology of future research and thus 
pave the way for new insights into the roles of tissue factor-bearing microparticles in the pathophysiology of various thrombotic disorders.

From a personal perspective, my PhD project has been a fascinating scientific odyssey into the largely unexplored interfaces between primary and secondary hemostasis. Looking forward, my ambition is to continue our work exploring platelet-coagulation interactions and to translate these insights into clinically meaningful information, which may someday improve treatments of patients with bleeding and/or thrombosis. 


\section{Tiable of Contents}

Part I: Basic concepts in hemostasis

\section{Introduction}

2. A brief overview of hemostasis

2.1 Mammalian hemostasis, biological function and evolutionary origins

2.2 Platelets

2.2.1 General characteristics of platelets: how and where to find them

2.2.2 How platelets are formed

2.2.3 How platelets recognize and attach to areas of vascular damage

2.2.4 How platelets accumulate at the site of injury

2.3 Secondary hemostasis

2.3.1 Current models of coagulation (as it happens in real life)

2.3.2 The intrinsic pathway of coagulation

4. Thrombin: the nexus between primary and secondary hemostasis

4.1 What is so special about thrombin?

4.2 The intricate ways in which thrombin activates platelets

4.2.1 Early observations of thrombin-platelet interactions

4.2.2 The discovery of PAR1 and PAR4

4.2.3 Modeling the functional roles of PAR1 and PAR4

4.2.4 PAR1 and PAR4 as therapeutic targets

4.3 How thrombin makes use of its exosites to activate PAR4

5.1 Platelets and coagulation factors: the yin and yang of hemostasis

5.1 Platelets as initiators of contact activation (Papers II and III)

5.2 Platelets, microparticles and tissue factor (Paper IV) 
Populärvetenskaplig sammanfattning på svenska 78

Studier av gränsytor mellan primär och sekundär hemostas 78 


\section{Abbrevations}

ADP Adenosine 5'-diphosphate

AMC 7-Amido-4-methylcoumarins

APTT Activated partial thromboplastin time

AT Antithrombin

ATP Adenosine 5'-triphosphate

CalDAG-GEFI Calcium diacylglycerol guanine nucleotide exchange factor I

CAT

Calibrated automated throm $\neg$ bogram

CMP Common myeloid progenitor cell

CTI Corn trypsin inhibitor

DAG 1,2-Diacyl-glycerol

DAPI 4',6-Diamidino-2-phenylindole

DIC Disseminated intravascular coagulation

DMSO Dimethyl sulfoxide

FRET Fluorescence resonance energy transfer

FITC Fluorescein isothiocyanate

FOR Free oscillation rheometry

GPCR G protein-coupled receptor

GTP Guanosine-5'-triphosphate

HSC Hemapoietic stem cell

IP3 Inositol-1,4,5-trisphosphate

LTA Light transmission aggregometry

MEP Megakaryocyte-Erythrocyte progenitor cell

MI Myocardial infarction

MMP Matrix metalloproteinase

NO Nitric oxide

Orai1 Calcium release-activated calcium channel protein 1

PAR Protease activated receptor

PBS Phosphate-buffered saline

PDGF Platelet-derived growth factor 


\begin{tabular}{|c|c|}
\hline PFP & Platelet-free plasma \\
\hline $\mathrm{PI}_{3} \mathrm{~K}$ & Phosphoinositide 3-kinase \\
\hline PIP2 & Phosphoinositide-4,5-bisphos $\neg$ phate \\
\hline PK & Plasma kallikrein \\
\hline PKC & Protein kinase $\mathrm{C}$ \\
\hline PLC & Phospholipase C \\
\hline PMP & Platelet-derived microparticles \\
\hline PPP & Platelet-poor plasma \\
\hline PRP & Platelet-rich plasma \\
\hline PS & Phosphatidylserine \\
\hline $\mathrm{PT}$ & Prothrombin time \\
\hline ROTEM & Rotational thromboelastometry \\
\hline SOCE & Store-operated calcium entry \\
\hline STIM1 & Stromal interaction molecule 1 \\
\hline TAFI & Thrombin-activatable fibrinolysis inhibitor \\
\hline TEG & Thromboelastography \\
\hline $\mathrm{TF}$ & Tissue factor \\
\hline TFMP & Tissue factor-exposing microparticle \\
\hline TG & Thrombin generation \\
\hline TNF & Tumor necrosis factor \\
\hline TP $\alpha$ & Thromboxane receptor $\alpha$ \\
\hline TPO & Thrombopoietin \\
\hline VEGF & Vascular endothelial growth factor \\
\hline VTE & Venous thromboembolism \\
\hline VWF & von Willbrand factor \\
\hline
\end{tabular}




\section{Part I: Basic concepts in hemostasis}
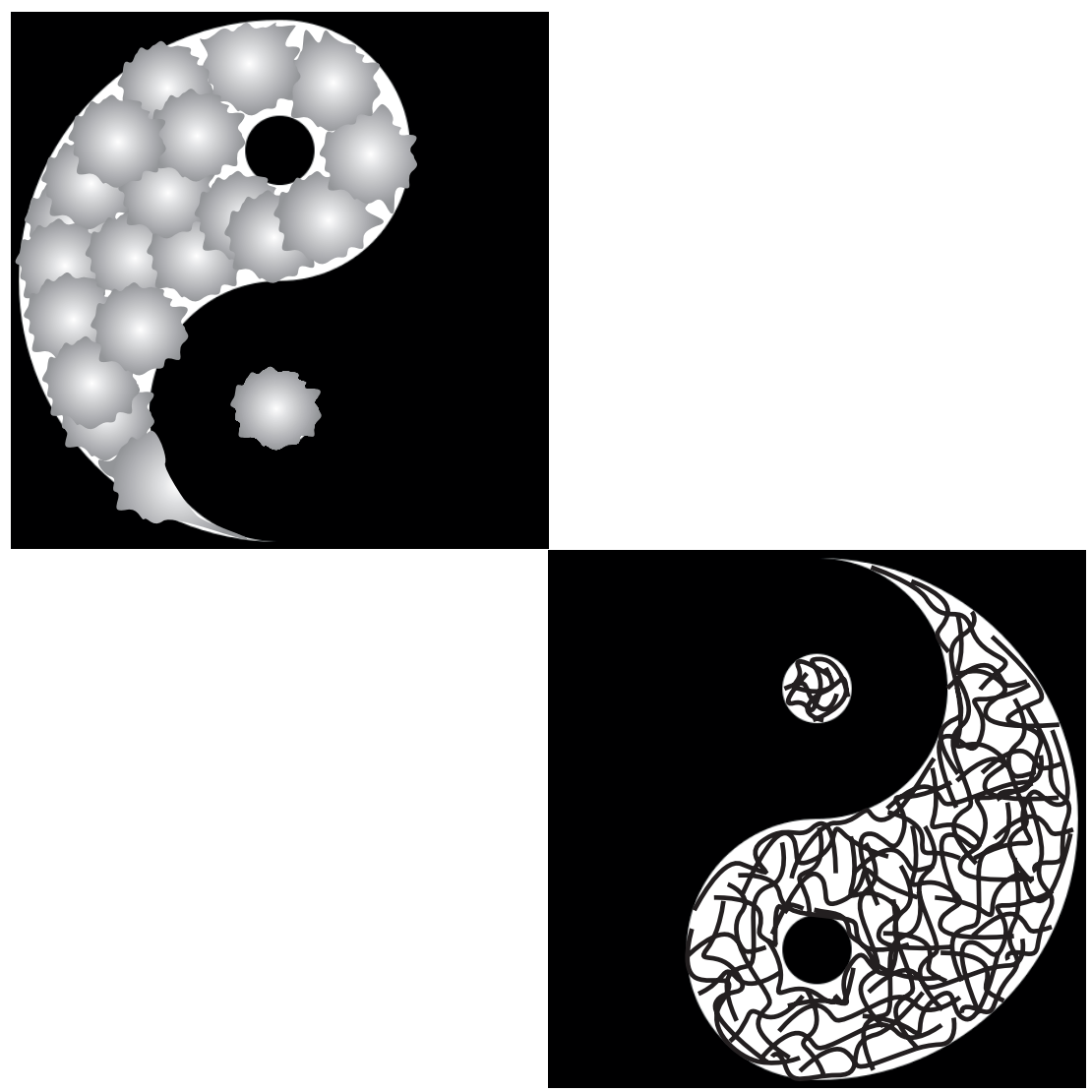


\section{Introduction}

In our struggle to understand hemostasis, it is certainly easy to be perplexed by the mind-boggling complexity of the systems involved. In fact, mammalian hemostasis has often been put forward as a proof for the concept of "irreducible complexity", used by creationists as a counter-argument to evolution, since it is hard to conceive how the multitude of inter-dependent regulatory nodes of the hemostatic system may have evolved in a stepwise fashion by the mechanisms provided by natural selection (Aird, 2003).

When thinking about complex things, human beings tend to divide the subject into smaller, more manageable parts that are thought of as separate entities. This tendency is clearly evident in traditional models of hemostasis, which divide the process into two separate steps occurring in chronological order upon vessel injury:

(1) Primary hemostasis involving vasoconstriction, platelet adhesion and platelet aggregation; and

(2) Secondary hemostasis mainly comprising fibrin formation and the development of a blood clot.

Due to its simplicity and tidiness, this dualistic "scheme" has powerful implications for the way people theorize about thrombosis and hemostasis (Heemskerk et al., 2013). In medical schools worldwide, students are trained to conceptualize bleeding and thrombosis in accordance with this division. Consequently, when a patient is referred to a hospital for a suspected bleeding disorder, clinicians are trained to focus their attention to signs in patient history, physical status and clinical work-up that are thought to differentiate between a defect in primary or secondary hemostasis. Moreover, different thrombotic disease states such as venous thromboembolism (VTE) and myocardial infarction (MI) have been categorized as mainly provoked by fibrin formation or platelet aggregation, and therapeutic interventions are designed to correct supposed pathological activation of the culprit system. However, as the focus of this thesis will be on the extensive interfaces between these seemingly separate systems, it will hopefully become evident to the reader that nature herself does not hesitate to violate our mental schemes when it suits her. 
Although the division of hemostasis into two separate and chronological steps certainly has some pedagogic merits, as all gross schematic terminologies it runs the risk of oversimplification to the point of blurring our understanding of the phenomena it is intended to describe. In fact, evidence of links between primary and secondary hemostasis have been around for more than a century.

Observations that the formation of low concentrations of thrombin, the protagonist enzyme in the coagulation cascade, potently activates platelets, thereby enhancing primary hemostasis, were first reported in 1917 (Wright and Minot, 1917). Decades ago, it was established that activated platelets bind coagulation factors and dramatically accelerate the coagulation cascade. In vivo models of thrombosis have shown that fibrin formation and platelet activation occur concomitantly and contribute to thrombus generation in both arterial and venous thrombosis in mice (Furie and Furie, 2005). Recently, it was claimed that stimulated platelets can single-handedly cause contact activation and initiate fibrin formation, thereby by-passing the tissue factor-dependent pathway of coagulation (Müller et al., 2010). Reports have also indicated that platelets and other blood cells can release microparticles with procoagulant membranes containing negatively charged phospholipids and tissue factor (van Es et al., 2015), thus providing an additional link between primary and secondary hemostasis.

In my $\mathrm{PhD}$ project, I have used the above findings as a starting point for my exploration of the ways in which platelets and coagulation factors work together to ensure hemostasis. The purpose of thesis is to provide a broader scientific context to the issues presented in the enclosed manuscripts. I will also briefly discuss how we have continued to study some of the issues raised therein. To acheive this, we will start off with a brief review of basic concepts in hemostasis (Part I). For readers with sparse knowledge of these issues, the content of Part I will hopefully suffice to make the following sections comprehensible. For readers already acquainted with the subject, it would make sense to head straight on to Part II, as the contents of Part I will be all too familiar. 


\section{A brief overview of hemostasis}

\subsection{Mammalian hemostasis, biological function and evolutionary origins}

The appearance of a closed cardiovascular system in early vertebrates some 525 million years ago (Shu et al., 1999) provided a strong selective pressure promoting the development of more sophisticated hemostatic mechanisms. Judging from observations in organisms with a more primitive circulation, it appears that up until then, hemostatic functions were mostly a part-time occupation of versatile cells tasked with such diverse functions as phagocytizing viruses and bacteria, releasing antibacterial factors, clotting the hemolymph and aggregate in response to injury (Iwanaga, 1993). Interestingly, in some invertebrates, hemostasis is achieved solely by aggregation of such cells at the site of injury (Ratnoff, 1987; Svoboda and Bartunek, 2015), whereas others also furnish their hemostatically active cells with the ability to clot the hemolymph by the release of one or more clotting factors (Madaras et al., 1979; Ravindranath, 1980).

But the presence of a high-pressure system, wherein blood is pumped out of the heart, pressed out into the arterioles and capillaries of distant organs, and then returned to the heart through the venous circulation, meant that unchecked bleeding rapidly could turn into a life-threatening event, and as a consequence, more sophisticated hemostatic system entered the stage. In what is often called "primary" or "cell-based" hemostasis, the protagonists are highly specialized cells or fragments of cells, capable of adhering to damaged vessel walls and aggregate to form a hemostatic plug, which serves to seal a wound (Ratnoff, 1987). With the exception of some reptiles such as alligators, most also developed the ability to contract the developing clot, thereby increasing clot elasticity and preventing vessel occlusion (Levin, 2013). In amphibia, reptiles, fish and birds, these cytoplasmic structures developed as nucleated cells called thrombocytes. In fish and birds, thrombocytes are morphologically difficult to distinguish from lymphocytes, but appear to be the most abundant among white blood cells (Bohls et al., 2006; Saunders, 1966).

In contrast, with the divergence from their lizard-like ancestors some 310 million years ago (Kumar and Hedges, 1998) evolution seems to have chosen a radically different path for cell-based hemostasis in mammals. Ever 
increasing demands on thrombocytes for flexibility and resistance to high shear due to increased blood pressure and thinner capillaries, probably provided the selective pressure to force the development a completely different system for production of mammalian hemostatic cells (Schmaier et al., 2012).

In the resulting unique hematopoietic process, endoreduplication of megakaryoblasts in the bone marrow produce polyploid megakaryocytes, which then utilize a sophisticated mechanism for "budding off" small anucleated cytoplasmatic fragments called platelets into the blood stream. The evolutionary origins of this unparalleled and highly sophisticated mechanism for production of hemostatic cells are largely unknown, due to the absence of intermediary forms that could be viewed as "prototypes" for the mammalian megakaryocytic system. However, several lines of indirect evidence suggest that mammalian platelets developed as orthologues to their non-mammalian counterparts, i.e. that platelets developed from thrombocytes and not de novo from other cell types (Svoboda and Bartunek, 2015).

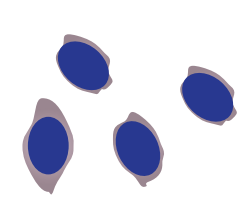

Fish

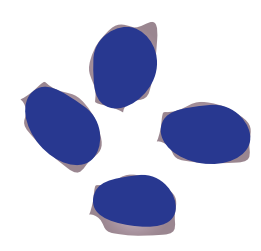

Frog

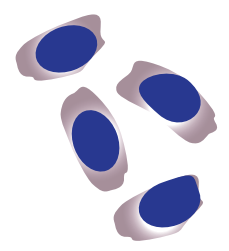

Bird

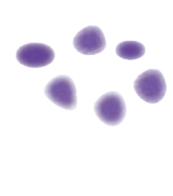

Human

Figure 1. Comparative drawing showing the visual appearance of thrombocytes from various species and human platelets. Redrawn from micrographs by (Svoboda and Bartunek, 2015).

Concomitantly, the foundations were laid for a separate "secondary" or factor-based hemostatic system, which as a minimum comprises the following two steps: (i) activation of a protease (thrombin) upon exposure of an activator (tissue factor) on the damaged vessel wall, leading to (ii) the polymerization of a monomer (fibrinogen), ultimately resulting in the gelling of blood known as coagulation. The presence of a prototypical coagulation system comprising the three abovementioned ingredients in the lamprey suggests that secondary hemostasis appeared more than 450 million years ago, before the evolutionary divergence of jawless vertebrates (Davidson et al., 2003). In what is likely a consequence of multiple gene duplications, 
new coagulation factors were later added, eventually giving rise to the complex mammalian blood coagulation network described in section 2.3.

Why then, did evolution simultaneously help to bring about two different highly specialized hemostatic systems, and what relation do they have with each other? Although the description above doesn't provide any direct answers to these questions, it is fascinating to contemplate that the multifunctional amebocytes and haemocytes of primitive invertebrates often have the capacity to cause both the gelling of blood which is often described as the end-point of coagulation and the formation of a hemostatic plug viewed as the final stage of primary hemostasis. In fact, I have failed to find any example of an organism which rely solely on coagulation for the prevention of bleeding, and with the exception of some primitive invertebrates, the same holds true for the opposite relation, i.e. the formation of a cell-based hemostatic plug without coagulation of some sort. These observations suggest that primary and secondary hemostasis have evolved not as separate entities but as intimately intertwined and complementary components of a single hemostatic system. 


\subsubsection{General characteristics of platelets: how and where to find them}

When looking at a blood film through a microscope, human platelets are identified as biconvex discoid structures with a diameter of 2-3 $\mu \mathrm{m}$, about a fifth of a normal-sized blood cell. Due to their appearance as small colorless corpuscles, untreated platelets are rather difficult to spot, but application of Giemsa dye turn them dark purple and readily identifiable. In healthy individuals, platelets are present at a particle concentration of 150-450 x $10^{9} / \mathrm{L}$ in whole blood, which means that they are approximately one order of magnitude less frequent than red blood cells. The average platelet life span is around 8-9 days (Harker et al., 2000), requiring a renewal rate of $10^{11}$ platelets/day to maintain the platelet pool intact. Approximately $30 \%$ of the entire platelet population is stored in the spleen, while the majority of platelets at any given moment are circulating freely in the blood. In the circulation, platelets are accumulated close to the vessel wall, due to rheological forces imparted by red blood cells, pushing platelets in a radial direction (Brass and Diamond, 2016). Thus, the boundary between the vessel wall and the blood is enriched 3-5-fold in platelets, while being virtually void of any red blood cells, enabling platelets to continuously scan the vascular wall for damage.

\subsubsection{How platelets are formed}

Platelet biogenesis depends on the sequential differentiation of hematopoietic stem cells (HSC) into common myeloid progenitor cells (CMP) and then into the megakaryocyte-erythrocyte progenitor cells (MEP), which finally dedicate themselves to life as a megakaryocyte under the influence of thrombopoietin (TPO) (Kaushansky et al., 1995). Human platelets are produced in the bone marrow by a unique process in which giant polyploid megakaryocytes produce long threadlike cytoplasmatic extensions called proplatelet processes that span the sinusoidal wall and stretch into venous pools of blood, the so-called myeloid sinusoids in the stromal compartment (Becker and De Bruyn, 1976). The proplatelet processes carry small proplatelet buds along their entire length, which essentially are immature platelet precursors waiting for the right signal to be released. The elongation of proplatelet processes is dependent on continuous polymerization of microtubules that slide against each other, pushing the extensions further away from the center of the parent cell (Patel et al., 2005). The microtubule network also serves as a critical transport hub for delivery of organelles and 
granules to the forming proplatelets (Kelley et al., 2000). The extensive branching of proplatelet processes observed during megakaryocyte maturation seem to be powered by myosin acting on actin filaments formed along the extensions (Italiano et al., 1999). The end tips of the proplatelet processes extending in to the sinusoid lumen constitute the birth place for new platelets, when the bulbous end tips of the processes finally bud of as discrete platelets or larger preplatelets which subsequently turn into regular platelets after additional fission. In this way, each individual megakaryocyte can produce thousands of platelets and release them into the blood stream (Harker and Finch, 1969).

\subsubsection{How platelets recognize and attach to areas of vas- cular damage}

While the life span of the vast majority of platelets is entirely uneventful, it is sufficient with a few transient stimuli to evoke an explosive response, turning these previously inert particles into powerful agents of hemostasis within a matter of seconds. This dramatic transition is made possible through a number of interactions between platelet receptors and extracellular ligands appearing at the site of vascular injury. To understand this remarkable feature of platelet physiology, it is necessary to consider some details of the vascular milieu in which platelets operate.

As platelets pass through the circulation, they continuously make contact with endothelial cells forming the outermost layer of the vasculature, forming a barrier towards the underlying extracellular matrix. Healthy endothelial cells release nitric oxide (NO), prostacyclin and CD39 which serve as potent negative regulators of platelet adhesion (de Graaf et al., 1992; Moncada et al., 1976) and activation (Azuma et al., 1986; Marcus et al., 1991), thus providing inhibitory signals to ensure that platelets stay in a resting state in the absence of vessel injury. Upon penetrating mechanical injury such as a cut, this endothelial barrier is disrupted, exposing prothrombotic surfaces that apart from Tissue Factor (TF) also contain collagen and von Willebrand factor (VWF) (Ruggeri and Mendolicchio, 2007). As blood is exposed to hydrophilic wound surfaces, deposition of plasma-borne VWF and fibrinogen on the extracellular matrix provides additional sites of interaction (Savage et al., 1996).

The initial adhesion of platelets to the site of injury is mainly mediated by interactions between the glycoprotein GpIba and immobilized VWF, with 
additional albeit weaker binding sites for VWF on platelets provided by $\alpha_{\mathrm{IIb}} \beta_{\mathrm{III}}$ (Hantgan et al., 1990). Successive strengthening of the interactions between VWF, collagen, GpIba and $\alpha_{\mathrm{IIb}} \beta_{\mathrm{III}}$ arrests the initial rolling movement of platelets on prothrombotic surfaces, and allows for binding of collagen receptors with lower affinity such as GPVI and $\alpha_{2} \beta_{1}$ (Chen et al., 2002). The physiological importance of VWF-GpIba interactions for hemostasis is illustrated by the severe bleeding phenotype displayed by individuals with von Willebrand disease type 3 and Bernard Soulier syndrome, associated with absence of VWF and GpIb, respectively.

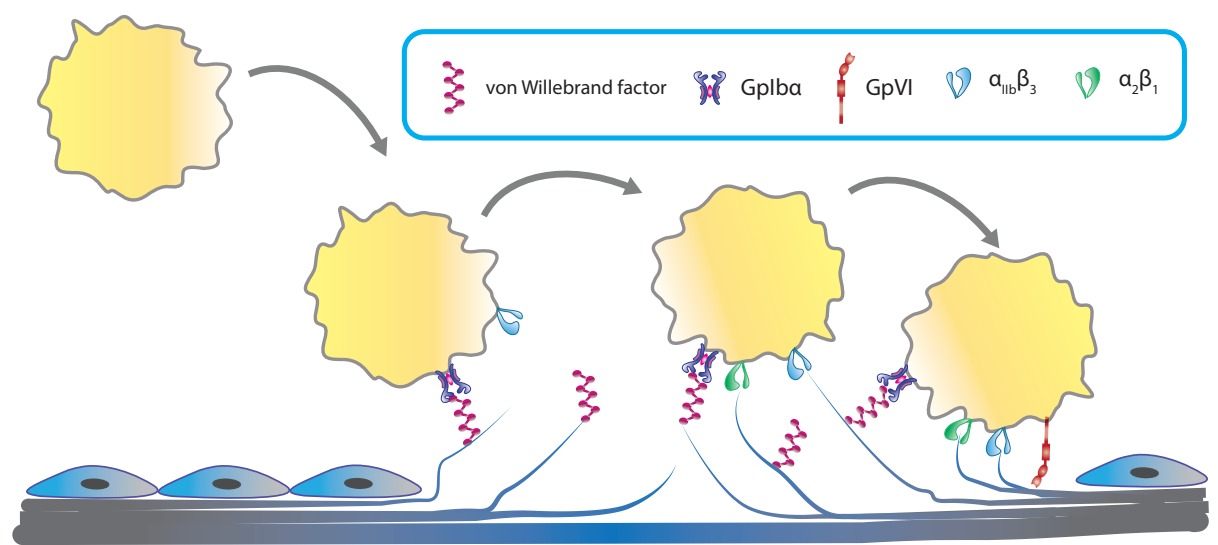

Figure 2. Schematic illustration of platelet adhesion to collagen exposed in a damaged vessel wall.

\subsubsection{How platelets accumulate at the site of injury to form a hemostatic plug}

Platelet adhesion to sites of vascular injury constitute the starting point for a cascade of tightly controlled events serving to ensure the formation of a mechanically stable and spatially confined thrombus. According to current models, platelets contribute to this process by (i) releasing a mix of bioactive substances which are synthesized de novo or stored in intracellular granules; (iii) mechanically recruiting additional platelets to the thrombus thereby forming a hemostatic plug; (iii) accelerating and localizing coagulation and (iv) tailoring the overall thrombus architecture to form distinct zones with heterogeneous structure and function (Brass and Wannemacher, 2011). Importantly, depending on the timing and localization of platelet 
recruitment to the growing thrombus, individual platelets activate different parts of this repertoire, leading to the differentiation of platelet subpopulations with distinct functions within different regions of the thrombus (Heemskerk et al., 2013). It is also important to emphasize that the type of vessel injured (artery, arteriole, capillary, vein) as well as the mechanism of injury (crush injury, penetrating injury, abrasion) are parameters that can produce very different hemostatic responses due to variations in blood shear forces and degree of exposure of blood to extracellular matrix proteins.

The initial stimulatory signal eliciting these responses in single platelets adhering to the damaged vessel wall is thought to be mediated by collagen receptors, of which GPVI is generally considered the most important (Li et al., 2010b). With the gradual build-up of a three dimensional thrombus, a panel of $\mathrm{G}$ protein-coupled receptors expressed on the platelet surface take over much of the stimulatory signaling as a response to the formation of diffusible platelet agonists within and around the thrombus, driving platelet recruitment and thrombus growth. Simultaneously, a build-up of inhibitory signals from negative-feedback loops counteracts the exponential increase in stimulatory signaling to prevent excessive thrombus formation (Bye et al., 2016).

As an extensive review of the intra- and extracellular pathways responsible for regulating these events are outside the scope of this thesis, we will instead try to summarize the most important nodes of the platelet clot-regulating network formed by (a) platelet receptors; (c) intracellular signaling proteins and (d) critical platelet hemostatic effector mechanisms. Hopefully, by focusing on the interconnectedness of the signaling pathways and not on the intricate details of each individual component, this approach will facilitate a holistic understanding of platelet-controlled hemostasis. 


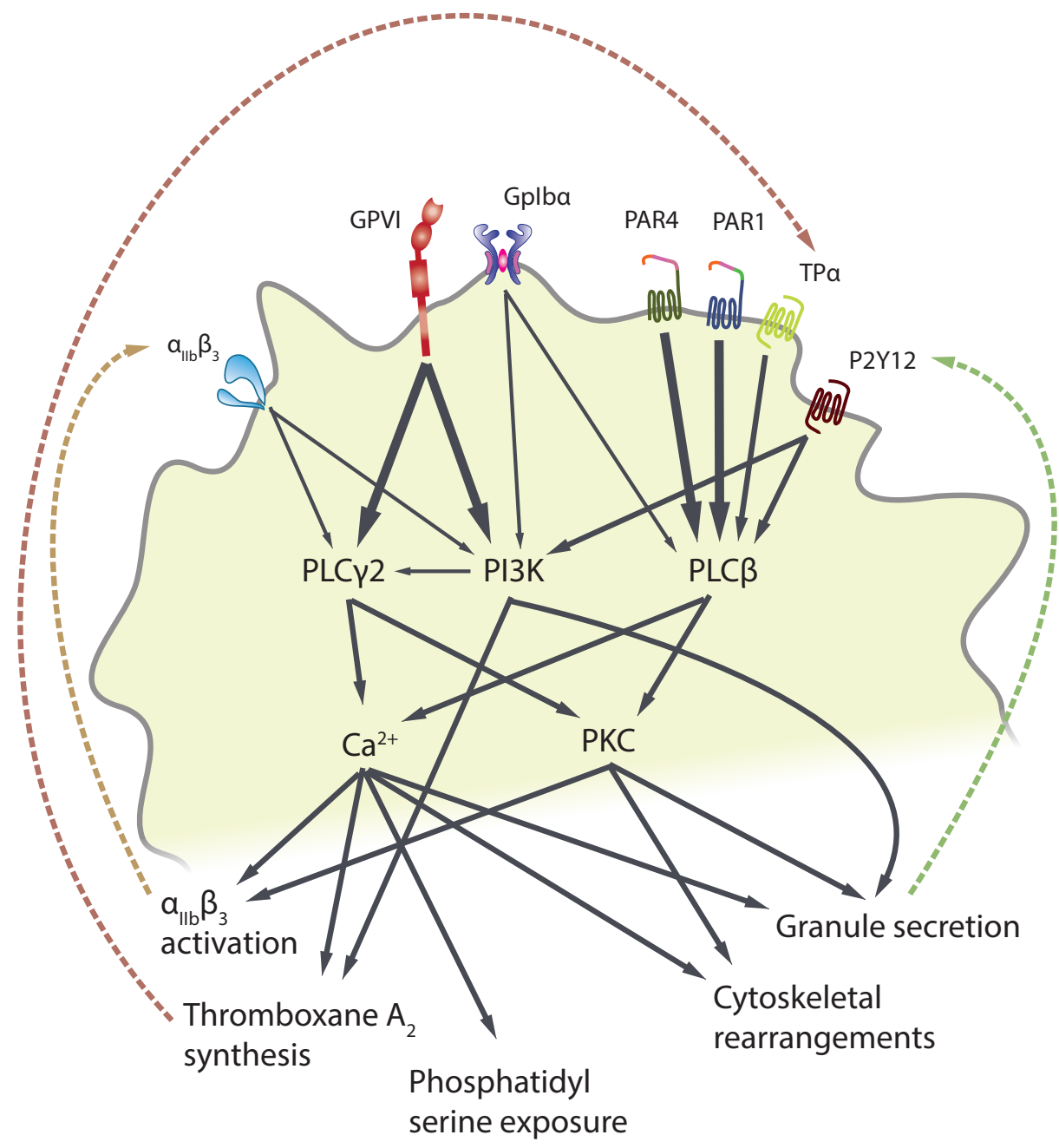

Figure 3. The major interconnected stimulatory nodes of the platelet clot-regulating network. Adapted from (Bye et al., 2016; Heemskerk et al., 2013). The glycoprotein receptors GPVI, GpIba and $\alpha_{I I b} \beta_{I I I}$ are shown on the left side, while the major G protein-coupled receptors PAR1, PAR4, TPQ and $P_{2} Y_{12}$ are placed at the right.

With the formation of a monolayer of platelets covering the prothrombotic surface of a damaged vessel wall, collagen-induced signaling via the glycoprotein GPVI and integrin $\alpha_{2} \beta_{1}$ lead to activation of phospholipase CY 
(PLCY) 2 and potentiation of this signal by phosphoinositide 3-kinases ( $\mathrm{PI} 3 \mathrm{Ks}$ ), causing a prolonged surge in intracellular calcium levels. For reasons not completely understood, this massive stimulatory input is translated into a heterogeneous response, with differential activation of hemostatic effector mechanisms in different populations of platelets. While a majority of platelets undergo a characteristic shape change with pseudopodia formation and strong aggregatory activity, clusters of less sticky platelets with only minor shape change display a dominantly procoagulant response. The latter cells accumulate in patch-like formations in periphery of the growing thrombus (Berny et al., 2010; Munnix et al., 2007). Whether this phenomenon is caused by an inherent heterogeneity in the platelet population or by differences in environmental conditions such as local rheology or stimulatory input is currently unclear, but concurrent stimulation by thrombin is known to increase the fraction of procoagulant platelets forming on collagen surfaces, probably related to increased intracellular calcium mobilization (Keuren et al., 2005).

Granule secretion and the accelerated formation of thrombin on procoagulant platelet membranes cause rapid activation of surrounding platelets and recruitment by aggregating platelets into the thrombus via crosslinking of $\alpha_{\text {IIb }} \beta_{\text {III }}$ and to a lesser extent GpIba with fibrinogen. Due to an exponential increase in thrombin concentration, the dominant stimulatory intracellular mechanism in these platelets is PLC $\beta$ and PKC, resulting in an oscillatory calcium signal eliciting most hemostatic effector mechanisms except for procoagulant activity (Heemskerk et al., 1997). Importantly, the strong composite stimuli resulting from simultaneous stimulation by thrombin, thromboxane, ADP and integrin outside-in signaling contribute to thrombus consolidation in the forming thrombus core, as the contractile mechanisms of platelets are activated, causing clot retraction (Ono et al., 2008). This process reduces thrombus porosity (Stalker et al., 2013; Welsh et al., 2012), thereby limiting thrombus propagation while also contributing to wound sealing.

Small molecules such as ADP and thromboxane are able to escape the physical barriers put in place by the formation of a thrombus core, resulting in a loosely packed shell of P-selectin negative platelets in the periphery. Since these runaway molecules are rapidly degraded in plasma and single-handedly provide insufficient stimuli, primarily via $\mathrm{PI}_{3} \mathrm{~K}$, to promote further granule secretion, this propagating "wave" of platelet agonists is thus spatially limited, thereby providing a mechanism for delineating the 
outer boundaries of the thrombus by regulating the spatial distribution of composite agonist gradients.

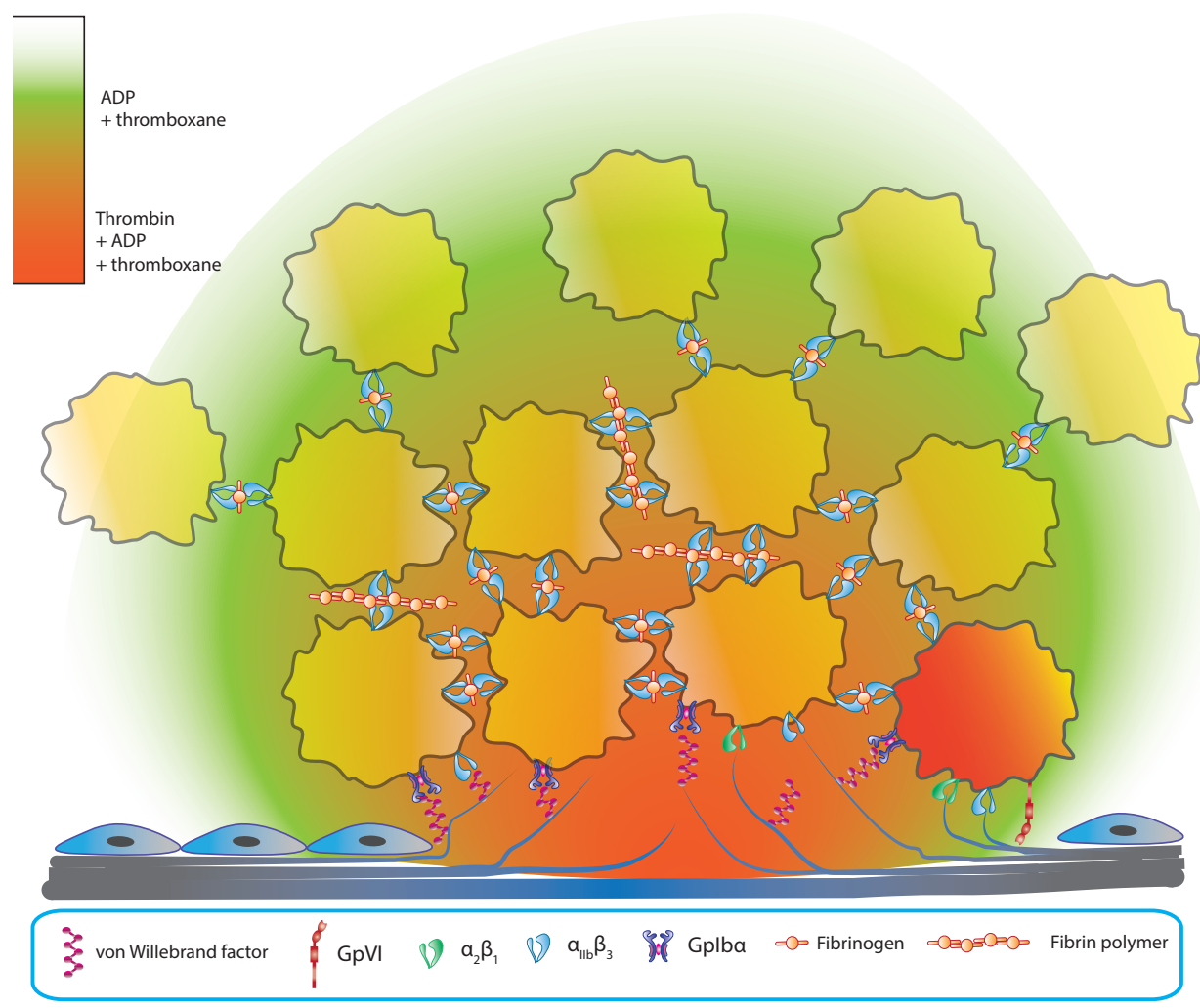

Figure 4. Schematic drawing illustrating the heterogenic architecture of a hemostatic plug. In the innermost layers of the thrombus, platelets receive a plurality of strong stimuli from collagen via receptors GPVI and $\alpha_{2} \beta_{1}$, thrombin via receptors PAR1 and PAR4 and paracrine agonists via P2Y12 and TPa. A minority of platelets (coloured red) making contact with collagen turn procoagulant, binding coagulation factors and accelerating thrombin generation, whereas most turn strongly pro-aggregatory by activating $\alpha_{I I} \beta_{3}$ to bind fibrinogen and fibrin. These platelets also initiate clot retraction. The two latter processes reduce thrombus porosity, limiting diffusion of thrombin to the outer layers of the thrombus. In the thrombus shell, platelets are exposed to low concentrations of smallsized agonists such as thromboxane $A_{2}$ and $A D P$, as well as minute quantities of thrombin. These weak stimuli are sufficient to produce partial activation of $\alpha_{I I b} \beta_{3}$ but inadequate to elicit granule secretion or $P$-selectin exposure. 


\subsubsection{Three critical events during platelet activation and how to measure them}

At this point, it is warranted to provide a brief review of three critical events during platelet activation (described in Figure 3), as measurement of these events form the basis of many of the experimental methods used in this thesis.

\section{Calcium mobilization}

Changes in intracellular calcium concentrations serve as a universal signaling event in a wide variety of cells. As evident from Figure 3, calcium mobilization is a central event in platelet activation, critical for mobilizing all hemostatic effector mechanisms in platelets. Calcium signaling triggered by PLC $\gamma 2$ and PLC $\beta$ occurs via hydrolysis of phosphoinositide-4,5-bisphosphate $\left(\mathrm{PIP}_{2}\right.$ ) to inositol-1,4,5-trisphosphate $\left(\mathrm{IP}_{3}\right.$ ) and 1,2-diacyl-glycerol (DAG). $\mathrm{IP}_{3}$ binds to $\mathrm{IP}_{3}$ receptors on the endoplasmatic reticulum, thereby evoking the release of intracellular calcium deposits (Berridge et al., 2003). DAG in turn stimulates the influx of calcium from the extracellular compartment by direct activation of calcium ion channels in the plasma membrane (Varga-Szabo et al., 2009). Another important mechanism of calcium mobilization from the extracellular space as a response to depletion of calcium in the endoplasmatic reticulum called store-operated calcium entry (SOCE) is mediated by STIM1 and Orai1 (Braun et al., 2009; Liou et al., 2005; Roos et al., 2005; Zhang et al., 2005). Increased calcium concentration results in a number of events, including activation of the GTPas Rap1 via CAlDAG-GEFI, triggering integrin activation and release of thromboxane $\mathrm{A}_{2}$ (Stefanini et al., 2009). Calcium mobilization in platelets can be conveniently measured by fluorescence spectroscopy using a variety of fluorescent intracellular calcium probes (Takahashi et al., 1999). It should be noted, however, that such methods require the use of washed platelets or platelet-rich plasma, and only report the average calcium concentration in a bulk of cells, whereas monitoring of calcium concentrations at the single cell level requires different experimental approaches (Heemskerk et al., 1997). 


\section{Granule release}

The ability of platelets to collect, store and release cargo is another central feature of platelet function, as illustrated by the bleeding phenotype of patients with inherited platelet secretion disorders (Dawood et al., 2012). Platelets store cargo in granular stores called $\alpha$-granules (alpha granules), $\delta$-granules (dense granules) and lysosomal granules, containing different sets of hemostatically active ingredients that are released upon activation by a calcium-dependent exocytotic mechanism (Golebiewska and Poole, 2013). As the physiological relevance of lysosomal release is currently unclear, only dense granules and alpha granules will be described in this section.

Dense granules have a size of approximately $150 \mathrm{~nm}$, are present at a copy number of 3-8/platelet and contain small molecules such as ADP, ATP, calcium ions, polyphosphates and serotonin, all of which are known to have pro-hemostatic activity. Defective biogenesis of dense granules is present in Hermansky-Pudlak syndrome, resulting in a mild but clearly abnormal bleeding phenotype (Gunay-Aygun et al., 2004). Rapid secretion of dense granule content upon platelet activation constitutes an important positive feedback-mechanism in thrombus formation, driving recruitment of platelets to the sire of injury via $\mathrm{P}_{2} \mathrm{Y}_{12}$ and influencing the core-shell architecture of the developing thrombus (Golebiewska and Poole, 2015). Dense granule release can be measured in vitro by a number of assays, e.g. luminescence assays in which ATP release is measured by a bioluminescent reaction catalyzed by firefly luciferase, or by measuring surface expression of CD63 using flow cytometry (Gresele et al., 2014).

The larger alpha granules contain a more heterogeneous cargo of proteins with a wide range of different effects on hemostasis and wound repair. Upon platelet activation, alpha granules constitute an important additional source of pro-hemostatic proteins such as von Willebrand factor (VWF), Factor V, Factor XI and prothrombin, boosting platelet adhesion and coagulation at the site of injury. Fusion of alpha granules with the platelet membrane during exocytosis also replenishes platelets with additional membrane proteins, enhancing their pro-hemostatic and pro-inflammatory activity. Apart from supplying new copies of receptors already present on the platelet membrane such as $\alpha_{\text {IIb }} \beta_{\text {III }}$ and GpIba-V-IX, alpha granule exocytosis also brings new proteins involved in platelet-neutrophil interactions such as P-selectin and CD4OL, to the platelet surface (Koseoglu and Flaumenhaft, 2013), making these proteins excellent markers of alpha granule 
release for use in flow cytometry (Michelson, 1996). Additional classes of proteins released from alpha granules are angiogenic factors such as VEGF, anti-angiogenic factors such as angiostatin and platelet factor IV, growth factors such as PDGF, proteases such as MMP-2 and MMP-9 and cytokines such as TNF- $\alpha$ (Coppinger et al., 2004). Somewhat predictably with regards to the diverse contents therein, defects in alpha granule secretion in Gray platelet syndrome confer a more diverse bleeding phenotype among patients (Nurden and Nurden, 2007) .

\section{Integrin activation}

Integrin activation is another hallmark of platelet activation with critical implications for hemostasis, constituting the major switch regulating whether platelets clump together in aggregates or remain resting (Coller and Shattil, 2008). Although there are a number of integrin receptors on the platelet surface, $\alpha_{\mathrm{II}} \beta_{\mathrm{III}}$ is by far the most abundant with a record surface density of approximately 80 ooo copies/platelet (Wagner et al., 1996). As shown in Figure $4, \alpha_{\mathrm{II}} \beta_{\mathrm{III}}$ mediate the cross-linking of platelets via fibrinogen or fibrin (Podolnikova et al., 2014). This event is preceded by inside-out signaling in which conformational changes in $\alpha_{\mathrm{II}} \beta_{\mathrm{III}}$ induce high-affinity ligand binding (Bennett, 2015). The critical, non-redundant role of $\alpha_{\mathrm{IIb}} \beta_{\mathrm{III}}$ is demonstrated by the severe bleeding observed in patients with Glanzmann thrombasthenia, a disorder characterized by the absence of functional $\alpha_{\text {IIb }} \beta_{\text {III }}$ on the platelet surface. $\alpha_{\text {IIb }} \beta_{\text {III }}$ ligand binding also induces outside-in signaling, resulting in actin polymerization and cytoskeletal reorganization, with important functional implications for platelet spreading, stabilization of platelet aggregates and clot retraction. $\alpha_{\mathrm{II}} \beta_{\mathrm{III}}$ activation can be measured indirectly using various aggregometry assays or by measuring fibrinogen binding by flow cytometry. The discovery of the antibody PAC- 1 also enabled direct measurement of the conformational changes in $\alpha_{\mathrm{IIb}} \beta_{\mathrm{III}}$ accompanying receptor activation using flow cytometry (Shattil et al., 1987). 


\subsection{Secondary hemostasis}

\subsubsection{Current models of coagulation (as it happens in real life]}

Blood coagulation, as it is understood today, is best described as a series of tightly controlled membrane-bound proteolytic reactions causing a localized gelling of blood as a consequence of fibrin polymerization (Monroe and Hoffman, 2006). The complexity of the coagulation system reflects the need to accommodate two strong, seemingly contradicting requirements put forward by natural selection: (1) to ensure massive generation of thrombin when needed to stop bleeding; and (2) to eliminate unwarranted coagulation to prevent thrombosis and maintain adequate perfusion of tissues. The intricate balance between these two conflicting job descriptions has led to the evolution of several amplification steps on the one hand, in which serial proteolytic reactions lead to an exponential increase in thrombin generation (Davie and Ratnoff, 1964; Macfarlane, 1964), and to a multitude of regulatory mechanisms and negative feed-back loops on the other, to limit and localize clot formation to the site of vascular injury.

Apart from the regulatory mechanisms built into the coagulation system itself, efficient coagulation is also dependent on the exposure of blood to different cell membranes, so that the blood-borne coagulation factors gain access to tissue factor (TF) expressed on subendothelial cells in the vasculature and to phospholipids on procoagulant platelets. These requirements constitute additional regulatory checkpoints as they necessitate (A) a damaged vasculature; and (B) the presence of strongly activated and immobilized platelets. Coagulation can also be triggered by the contact activation pathway, and this alternative route of secondary hemostasis will be discussed in the end of this chapter.

Conceptually, tissue factor-driven coagulation can be divided into three distinct phases: initiation, amplification and propagation (Hoffman and Monroe, 2001). In the initiation phase, TF expressed on subendothelial cells is exposed to blood, forming a complex with FVII which is then converted to its active form, FVIIa. The TF-FVIIa complex activates FX and FIX. Still bound to the membranes of TF-expressing cells, FXa then binds to and activates FV to form the prothrombinase complex, leading to the conversion of small amounts of prothrombin to thrombin (FIIa). 


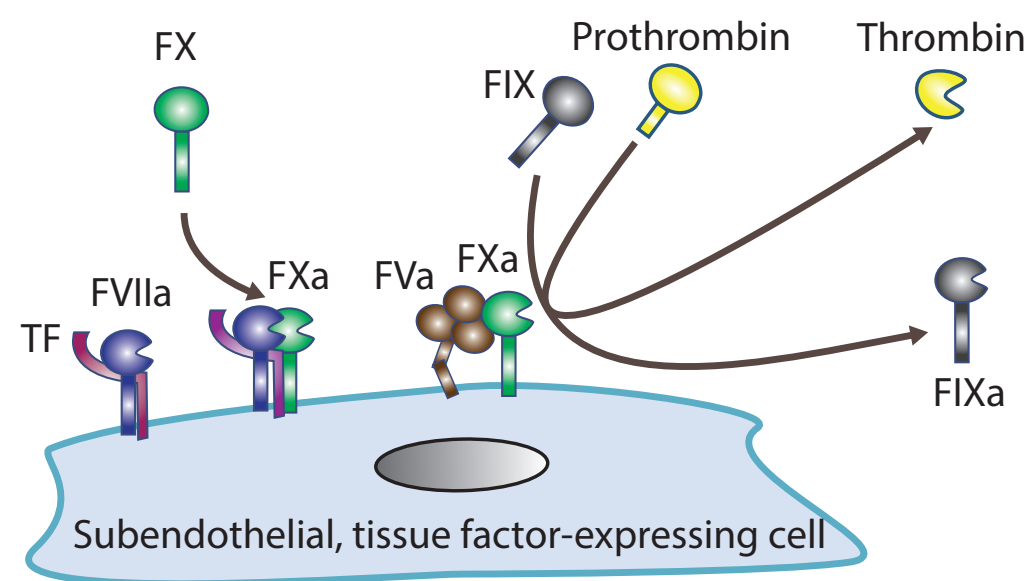

Figure 5. Initiation phase of coagulation. Adapted from (De Caterina et al., 2013; Monroe and Hoffman, 2006; Versteeg et al., 2013)

In the amplification phase, thrombin generated in the last step of the initiation phase diffuse away from the membranes of TF-expressing cells, encountering platelets adhering to collagen fibers in the subendothelial matrix. Already activated by collagen, the adhering platelets receive further stimulation when exposed to thrombin, and this compounding of potent stimuli is sufficient to generate a sustained increase of platelet intracellular calcium concentrations, turning a sizeable fraction of the stimulated platelets procoagulant, meaning that they by exposing phosphatidylserine in the outer layer of the cell membrane can bind to coagulation factors and increase their proteolytic activity. With thrombin still binding to the platelet surface receptor GpIba and having stimulated platelets via the PAR receptors, it now turns its attention to the platelet-bound fractions of coagulation factors V, VIII and XI, the activation of which marks the beginning of the ultimate phase of coagulation. 


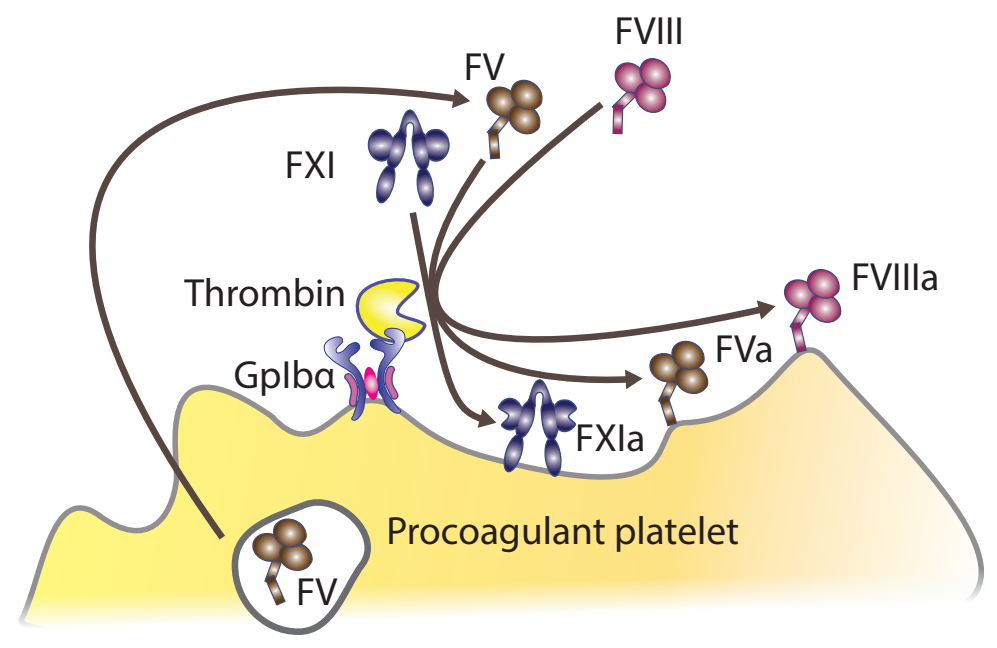

Figure 6. The amplification phase of coagulation. Adapted from (De Caterina et al., 2013; Monroe and Hoffman, 2006; Versteeg et al., 2013)

The propagation phase involves the formation of the tenase and prothrombinase complexes on the surfaces of procoagulant platelets. Newly formed FXIa activates platelet-bound FIX, enabling the assembly of the tenase complex comprising FVIIIa and FIXa. The formation of the tenase complex leads to generation of massive amounts of $\mathrm{FXa}$, which then associates with FVa, most of which is released from the $\alpha$-granules of procoagulant platelets (Briede et al., 2001). Together, FXa and FVa associate on the surface of procoagulant platelets forming the prothrombinase complex, finally giving rise to an explosive surge in thrombin generation. With massive amounts of thrombin now diffusing away from the activated platelets, fibrinogen cleavage and fibrin polymerization rapidly ensues, turning the previously fluid surrounding blood into a gelatinous mass. 


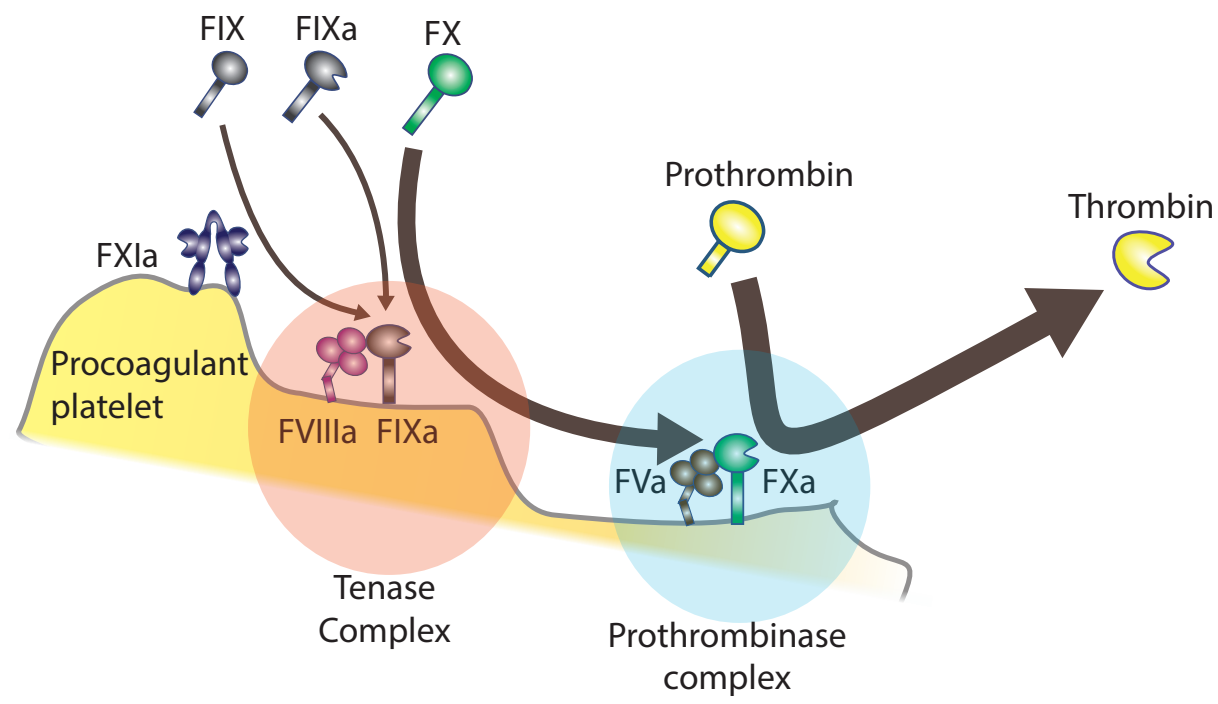

Figure 7. The propagation phase of coagulation. Adapted from (De Caterina et al., 2013; Monroe and Hoffman, 2006; Versteeg et al., 2013)

At various stages in this process, activated coagulation factors bound to endothelial cells or suspended in plasma are at constant threat of inactivation by circulatory antithrombotic molecule such as antithrombin (inhibits FXa and thrombin), tissue factor pathway inhibitor (inhibits FXa) and in a later stage activated protein C (inhibits FVa, FVIIIa), whereas assembly into complexes binding to the platelet membrane confers protection from these inhibitors (Oliver et al., 2002; Olson et al., 1993). Also, the "bursts" of thrombin generation achieved in the vicinity of procoagulant platelets with functional prothrombinase and tenase complexes, leads to activation of factor XIII (Lorand, 2001) and TAFI (Bajzar et al., 1995), protecting the nascent fibrin fibers from inactivation by plasmin.

At this point, it is important to emphasize a few different aspects of the coagulation system relevant to the subject of this thesis. Firstly, it is evident from the description above that platelets are key regulators of coagulation, providing a procoagulant surface at which the coagulation factors can find each other and associate into enzyme complexes, but also being important suppliers of various coagulation factors such as FV and providing protection from inactivation by various endogenous anticoagulants. This means 
that coagulation is largely restricted to areas containing strongly activated platelets, an important safeguard against uncontrolled thrombosis.

Secondly, the scheme outlined above shows that thrombin is generated in two different phases of coagulation, first in minute quantities with little consequences for fibrin formation, and later in the propagation phases in a massive burst of activity in which all available fibrinogen is rapidly polymerized. Thus, different populations of platelets are exposed to two radically different thrombin concentration gradients at different time-points, an observation relevant to our upcoming discussion regarding the mechanisms of thrombin-induced platelet activation.

Thirdly, although not obvious from the description above, it is important to note that only a small fraction $(<5 \%)$ of the thrombin generated during the propagation phase of coagulation is needed to effect clotting of whole blood as measured by standard clinical coagulation testing such as the prothrombin time (PT) and the activated partial thromboplastin time (APTT). This interesting observation implies that most of the thrombin generated during coagulation must be ascribed other hemostatic functions, including platelet activation (Mann et al., 2003). The notion that thrombin generation has important functions apart from fibrinogen cleavage is supported by the observation that mice with profound hypofibrinogenemia are only mildly symptomatic (Suh et al., 1995), whereas deletion of thrombin or key enzymes in the coagulation cascade invariably lead to a lethal bleeding phenotype (Cui et al., 1996; Suh et al., 1995; Sun et al., 1998).

\subsubsection{The intrinsic pathway of coagulation}

Before we round up this overview of the coagulation system, it is necessary to introduce some concepts of the intrinsic pathway of coagulation, which will be the focus of section 5.1. Although it had been known for a long time that exposure of blood to foreign surfaces such as glass or sand can trigger coagulation, the first comprehensive characterization of this enigmatic phenomenon was presented by Ratnoff et al. in 1964 (Davie and Ratnoff, 1964). After a decade of work, Ratnoff had succeeded in isolating a protein lacking in patients with blood that failed to clot when exposed to glass or other negatively charged surfaces (Roberts, 2003). This protein, initially called Hageman factor after the first patient that was found to have this deficiency and later called factor XII (FXII), was found to be capable of independently 
triggering the clotting of blood via a cascade of proteolytic reactions dubbed the intrinsic pathway of coagulation.

In subsequent investigations, it was found that contact with negatively charged surfaces induces conformational changes in FXII resulting in autocatalysis of small amount of FXII into FXIIa (Samuel et al., 1992). FXIIa then cleaves plasma kallikrein (PK) which acts reciprocally to convert additional FXII into FXIIa (Cochrane et al., 1973). In a proteotypical cascade of proteolytic reactions, FXIIa proceeds by activating FXI and FXIa activates FIXa, leading to the formation of the tenase complex after association with FVIIIa. In this chain of events, the intrinsic pathway of coagulation ultimately converges with the so-called extrinsic pathway of coagulation in the formation of the prothrombinase complex. Importantly, the empirical data generated when investigating these phenomena was exclusively gathered from in vitro experiments on plasma samples, where the absence of cells was substituted with phospholipid reagents, explaining the discrepancy between this partially outdated model of coagulation and the cell-based model presented previously in this chapter (Monroe and Hoffman, 2006).

Curiously, patients with a deficiency in FXII did not seem to suffer from excessive bleeding, and Mr. Hageman himself died from pulmonary embolism after being bedridden for an extended period of time due to a fracture of the hemipelvis (Ratnoff, 1980). As these observations strongly indicated that the intrinsic pathway is dispensable for hemostasis, research on the possible role of FXII in hemostasis and thrombosis was largely put on hold for several decades (Caen and $\mathrm{Wu}, 2010$ ), leaving way for an intensified effort to determine the mechanisms for tissue factor-induced coagulation. In this process, most of the components of intrinsic pathway of coagulation (FXI, FIX, FVIII) were ultimately found to be integral components of the amplification and propagation phase of tissue factor-induced coagulation (Bauer et al., 1990; Gailani and Broze, 1991; Oliver et al., 1999; Osterud and Rapaport, 1977; Walsh, 2004), explaining why individuals with deficiencies in these factors display a clinically relevant bleeding phenotype. 


\section{Experimental methods}

The prevailing dualistic view of hemostasis discussed in the introduction is also reflected in the way we measure hemostatic function, both in the clinic and when doing research. Most traditional methods are designed to allow for the study of either primary hemostasis or secondary hemostasis in isolation, thereby omitting the important interfaces between the two systems. For example, the most commonly used methods to study coagulation in the clinic, the activated partial thromboplastin time (APTT) and the prothrombin time (PT) are performed in plasma depleted of platelets, necessitating the addition of phospholipids to substitute for the lack of procoagulant platelet membranes.

On the other side of the spectrum, light transmission aggregometry (LTA), generally considered as the gold standard for platelet function testing, is often performed in washed platelets and only measures the ability of platelets to aggregate, without the contribution of fibrin fibers strengthening the hemostatic plug. The problematic nature of this reductionist approach to hemostasis is illustrated in the case of Scott syndrome, a platelet function disorder characterized by deficient formation of procoagulant platelets (Lhermusier et al., 2011). Patients with Scott syndrome, have perfectly normal results on the above tests despite exhibiting a clearly abnormal bleeding phenotype.

During the last decades, several assays for "global" hemostasis analysis (ROTEM, TEG, FOR) have been gaining ground in the clinic, especially for use as point-of-care instruments in operating theaters and intensive care units. Such methods enable multiparametric analysis of clot formation where the contribution of coagulation factors and platelets can be measured, and can also theoretically assess the contribution of each system to the other (Tynngård et al., 2015). However, real-life experience has shown that viscoelastic analysis is rather insensitive to platelet dysfunction (Wegner et al., 2010). Moreover, as these assays involve artificial anchoring of the coagulum to surfaces, dysfunctional platelet adhesion is not registered (Lancé, 2015).

Thrombin generation measurements on platelet-rich plasma have been used as a functional method to assess the contribution of procoagulant platelet formation to coagulation (van der Meijden et al., 2005; Tardy-Poncet et al., 2009). Platelet exposure of procoagulant membranes upon activation can also be assessed using flow cytometry, by applying probes such as annexin $\mathrm{V}$ 
or lactadherin (Albanyan et al., 2009; Andree et al., 1990; Dachary-Prigent et al., 1993; Reutelingsperger et al., 1988; Thiagarajan and Tait, 1990).

In this thesis, I have used a panel of experimental methods to investigate different aspects of platelet function, such as aggregation, granule secretion, calcium mobilization, exposure of procoagulant membranes and clot retraction. I have also used two methods that allow for an assessment of the contribution of platelets to coagulation, the calibrated automated thrombogram (CAT) for measuring thrombin generation and free oscillation reometry (FOR) for measuring clot elasticity. As a comprehensive review of each of these methods is outside the scope of this text, Figure 8 is provided to give a schematic overview of the techniques and their analytic principles. 


\begin{tabular}{|c|c|c|c|c|}
\hline Method & Material & Detection method $F$ & Functional correlate & Read-out \\
\hline $\begin{array}{l}\text { Light } \\
\text { Transmission } \\
\text { Aggregometry } \\
\text { (LTA) }\end{array}$ & PRP, WP & Light absorbance & $\begin{array}{l}\text { Platelet aggregation } \\
\text { (activation of } \\
\text { integrin } \alpha_{\| 1} \beta_{3} \text { ) }\end{array}$ & \\
\hline $\begin{array}{l}\text { Flow } \\
\text { Cytometry } \\
\text { (FACS) }\end{array}$ & WB, PRP, WP & $\begin{array}{l}\text { Fluorescence } \\
\text { of individual } \\
\text { platelets (due to } \\
\text { binding of fluorescently } \\
\text { labelled molecules) }\end{array}$ & $\begin{array}{l}\text { Surface exposure } \\
\text { of markers } \\
\text { (e.g. P-selectin, } \alpha_{\| b} \beta_{3^{\prime}} \\
\text { phosphatidylserine) }\end{array}$ & \\
\hline $\begin{array}{l}\text { Intracellular } \\
\text { calcium }\end{array}$ & WP, PRP & $\begin{array}{l}\text { Fluorescent signal } \\
\text { from intracellular } \\
\text { calcium probe }\end{array}$ & $\begin{array}{l}\text { Platelet intracellular } \\
\text { calcium mobilization }\end{array}$ & \\
\hline $\begin{array}{l}\text { Whole blood } \\
\text { aggregometry } \\
\text { (Multiplate) }\end{array}$ & WB & $\begin{array}{l}\text { Impedance between } \\
\text { two electrodes }\end{array}$ & Platelet aggregation & \\
\hline $\begin{array}{c}\text { Thrombin } \\
\text { generation (TG) }\end{array}$ & PRP, PPP & $\begin{array}{l}\text { Fluorescence from } \\
\text { fluorogenic thrombin } \\
\text { substrate }\end{array}$ & $\begin{array}{l}\text { Thrombin } \\
\text { concentration }\end{array}$ & \\
\hline $\begin{array}{l}\text { Free oscillation reometry } \\
\text { (ReoRox) }\end{array}$ & WB, PRP, PPP & $\begin{array}{l}\text { Frequency and } \\
\text { dampening of } \\
\text { free oscillations }\end{array}$ & $\begin{array}{l}\text { Clotting time and } \\
\text { clot viscoelasticity }\end{array}$ & \\
\hline Western Blot & PRP, WP & $\begin{array}{l}\text { Chemoilluminescence } \\
\text { from secondary antibody } \\
\text { after separation of proteins } \\
\text { according to size }\end{array}$ & $\begin{array}{l}\text { Qualitative and } \\
\text { quantitative } \\
\text { analysis of } \\
\text { individual proteins } \\
\text { in a mixture }\end{array}$ & \\
\hline
\end{tabular}

Figure 8. Examples of experimental methods used in this thesis 
Part II: Interfaces

between primary and

secondary hemostasis

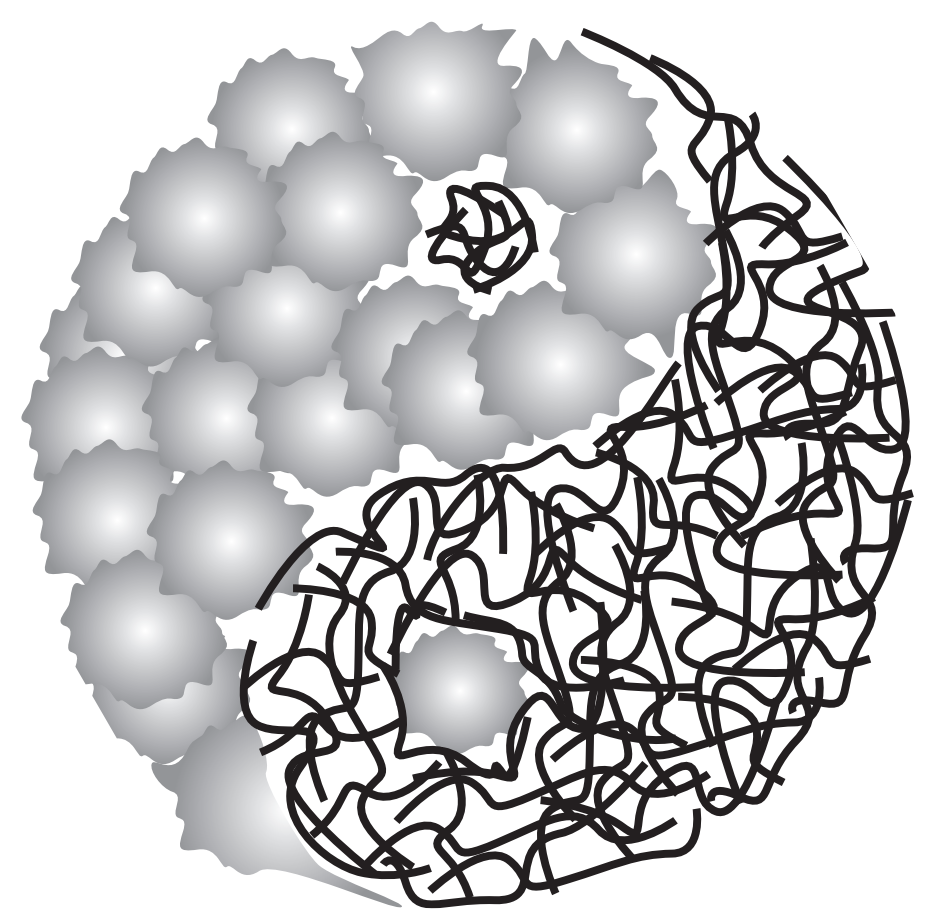




\section{Thrombin: the nexus between primary and secondary hemostasis}

\subsection{What is so special about thrombin?}

Thrombin (FIIa) is a $\mathrm{Na}^{+}$-activated serine protease formed after enzymatic proteolysis of prothrombin (FII) by the prothrombinase complex (Di Cera, 2008). The conversion of prothrombin into thrombin involves proteolysis of an internal peptide bond whereby one Gla and two kringle domains are cleaved off, leaving the resultant $36 \mathrm{kDa}$ enzyme stripped of everything except the serine protease domain necessary for catalytic activity. Phylogenetic evidence imply that thrombin predated and most likely gave rise to the other vitamin K-dependent coagulation factors (FVII, FIX, FX), validating the claim that thrombin constitutes the central component of protein-based hemostasis (Krem and Di Cera, 2001). The evolutionary origins of thrombin can be traced back to the divergence of the enzyme from complement factors in members of the deuterostome superphylum (Krem and Di Cera, 2002).

The remarkable functional versatility of thrombin is displayed by its ability to cleave a broad range of coagulation factors (FII, FXI, FV, FVIII, fibrinogen) as well as an important endogenous anticoagulant (protein C), the latter after modulation of its specificity by thrombomodulin. The proteolytic activity of thrombin is mainly dependent on three functionally important epitopes, the active site and two anion-binding exosites located at opposite ends of the enzyme, called exosite I and II. The binding of thrombin exosites to various epitopes are important for anchoring the enzyme to the substrate and enable catalysis, but also for allosteric modifications modulating the specificity of the enzyme (Petrera et al., 2009). While exosite I is important for binding to fibrinogen (Ayala et al., 2001; Scheraga, 2004) and thrombomodulin ( $\mathrm{Xu}$ et al., 2005), exosite II is critical for binding to heparins and glucosaminoglycans (Li et al., 2004, 2010a) as well as the fibrinogen Y' chain (Pineda et al., 2007). 


\subsection{The intricate ways in which thrombin activates platelets}

\subsubsection{Early observations of thrombin-platelet interactions}

When Wright and colleagues in 1917 noted that "the viscous metamorphosis of platelets" observed when mixing platelets with coagulating blood "was due essentially to thrombin"(Wright and Minot, 1917), this observation constituted the first proof for that blood coagulation could initiate cellbased hemostasis, placing thrombin at the nexus of the hemostatic network by tying together the endpoint of coagulation with the initiation of platelet aggregation. Curiously, five decades would come to pass before important progress was made towards understanding the role of thrombin in primary hemostasis.

By the 1970s, extensive efforts by several groups to understand the molecular basis of platelet-thrombin interactions had produced the following irrefutable obserations: (i) the enzymatic activity of thrombin is required for eliciting a stimulatory response in platelets (Davey and Luscher, 1967; Tam and Detwiler, 1978); (ii) binding of thrombin to the platelet surface is a prerequisite for platelet activation (Tollefsen et al., 1974); (iii) platelets contain numerous binding sites with both high and low affinity for thrombin (Tam and Detwiler, 1978; Tollefsen et al., 1974); and (iv) thrombin binds to but does not cleave GpIb (Detwiler and Feinman, 1973; Ganguly, 1974; Jamieson and Okumura, 1978; Mohammed et al., 1976; Okumura and Jamieson, 1976; White et al., 1981).

These observations were incorporated into models wherein thrombin was proposed to bind several different molecules on the platelet surface (Tollefsen et al., 1974), or where one single class of binding sites displays negative cooperativity upon binding to thrombin (Tollefsen and Majerus, 1976). Despite these advances, progress in the field was severely hampered by the failure to identify one or more receptor(s) responsible for transmitting the stimulatory signal upon binding of thrombin to the platelet surface. 


\subsubsection{The discovery of PAR1 and PAR4: Why are two recep- tors better than one?}

The crucial piece of the puzzle laid out by the above studies was finally put into place in the 1990 s when two different groups independently identified the presence of $\mathrm{G}$ protein coupled receptors (GPCRs) on the platelet surface, responsible for transmitting stimulatory signaling upon exposure to thrombin (Rasmussen et al., 1991; Vu et al., 1991b). Before the end of the millennium, rapid progress had enabled a detailed understanding of thrombin-induced platelet activation, which was shown to occur by means of two thrombin receptors in humans, termed Protease activated receptor (PAR) 1 and 4 (Kahn et al., 1998; Xu et al., 1998). It was shown that thrombin cleaves the extracellular N-terminal portion of PAR1 and PAR4, exposing a tethered agonist ligand which binds intramolecularly to the receptor, thereby inducing transmembrane signaling (Chen et al., 1994; Vu et al., 1991a).

In recombinant cell models expressing each receptor individually, thrombin binding to PAR1 was enhanced by interactions between Exosite I, a negatively charged region on thrombin, and a hirudin-like domain on PAR1 situated close to the tethered ligand, enabling receptor activation at picomolar concentrations of thrombin (Chen et al., 1994), whereas PAR4 was found to be approximately one order of magnitude less sensitive to thrombin, seemingly relying on dual proline residues and an anionic cluster to effect direct binding to the active site and slow down dissociation of the protease (Jacques and Kuliopulos, 2003). The interaction between GpIba and exosite II on thrombin was shown to accelerate the hydrolysis of PAR1 (De Candia et al., 2001), thereby further increasing the sensitivity of PAR1 for thrombin stimulation. Interestingly, stimulatory signaling from PAR1 and PAR4 displayed distinct temporal profiles, with PAR4 signaling being more prolonged (Shapiro et al., 2000), resulting in a more extended period of intracellular calcium mobilization (Kahn et al., 1998). Kinetic studies indicated that PAR4 proteolysis occurs over an extended time period, whereas PAR1 is rapidly cleaved, partially explaining this phenomenon (Covic et al., 2000). 

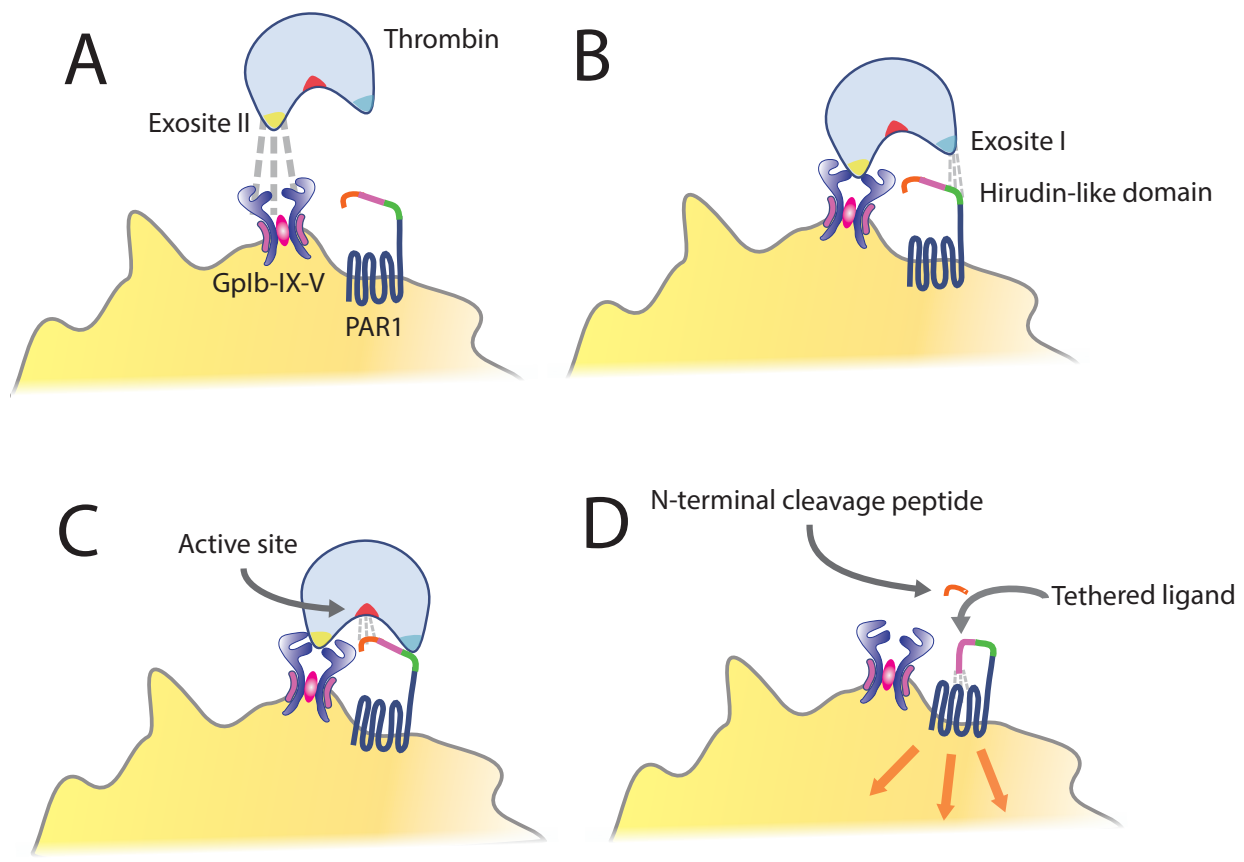

Figure 9. Schematic illustration of proposed model for thrombin-induced activation of PAR1.

As is so often the case in biology, the answer provided by the above studies gave rise to new, equally challenging questions. Why would nature choose such a complicated mechanism for platelet-thrombin interactions, involving at least three different receptors? And what are the individual roles of each receptor? The field grew even more complex as it was simultaneously discovered that mice harbor a different set of PAR receptors responsible for thrombin-induced platelet activation, PAR4 and PAR3 (Nakanishi-Matsui et al., 2000). PAR3 was found to be essentially non-signaling in mice, primarily functioning as a cofactor for PAR4, the receptor responsible for transmembrane signaling in response to thrombin stimulation. What was the evolutionary basis for the divergent evolution of PAR receptor configurations in different mammals? 


\subsubsection{Modeling the functional roles of PAR1 and PAR4 in thrombin-induced platelet activation}

Bearing on the findings that PAR1 and PAR4 displayed different affinities for thrombin, it was postulated that the PAR1/PAR4 receptor configuration could supply a mechanism for modulating the platelet response to low versus high thrombin concentrations (Coughlin, 1999), a concept that would imply differential effects of PAR1 and PAR4 signaling in platelets. This notion was to be explored further in subsequent studies focusing on the hemostatic response to PAR1 versus PAR4 activation, but the emerging results seemed to imply that the concept of PAR1 and PAR4 as high versus low affinity receptors for thrombin was overly simplistic.

One interesting early observation was provided when exposing platelets to thrombin in the presence of YD-3, a selective small-molecule inhibitor of PAR4 developed by $\mathrm{Wu}$ and colleagues in 2002 (Wu et al., 2002). It was found that YD-3 completely inhibited thromboxane synthesis at low concentrations of thrombin (Sambrano et al., 2001), seemingly contradicting the earlier categorization of PAR1 and PAR4 as high and low affinity thrombin receptors.

Three years later, in an exhaustive effort to elucidate the mechanism for thrombin-induced platelet activation, a group led by professor Kuliopulos used RWJ-56110, a competitive antagonist of the PAR1 tethered ligand (Andrade-Gordon et al., 1999), to show that thrombin-induced activation of platelets via PAR4 occurred at concentrations only twofold higher than those required to activate platelets via PAR1 (Leger et al., 2006). Using a variety of experimental models and techniques, it was shown that PAR1 and PAR4 form heterodimers on the platelet surface, and that coexpression of PAR1 and PAR4 seemed to enhance thrombin-induced PAR4 activation (Arachiche et al., 2013; Leger et al., 2006). Thus, a new model was proposed wherein PAR1, apart from functioning as a thrombin-sensing receptor in itself, also served as a cofactor for PAR4 activation. Years later, it was shown that PAR4 expressed in HEK cells also readily forms stable homodimers (de la Fuente et al., 2012). Although the functional consequences of this receptor configuration remains uncertain, mutational analysis of the regions forming the interaction interface (transmembrane helix 4) reduced calcium signaling in the recombinant system. 
Studies aimed at assessing the potential functional differences between thrombin-induced activation of PAR1 and PAR4 on hemostasis produced somewhat conflicting results. Research from our group conducted with polyclonal antibodies shown to inhibit PAR4 and the selective PAR1 inhibitor $\mathrm{SCH} 79797$ (Ahn et al., 1999) demonstrated that PAR4 activation appear to increase clot elasticity and protect from clot lysis, while PAR1 activation was found to promote fibrinolysis (Vretenbrant et al., 2007). Other groups reported differential effects on platelet spreading on fibrinogen-coated surfaces (Mazharian et al., 2007) and on $\alpha_{2} \beta_{1}$-mediated adhesion to collagen (Marjoram et al., 2009). Although differences in granule release as a response to stimulation or the respective receptor was reported in 2005 (Ma et al., 2005), these findings could not be replicated in subsequent studies by us (unpublished results) and others (Jonnalagadda et al., 2012). Interestingly, a recent study wherein a FRET-based sensor was used to scan for thrombin activity on the platelet membrane during thrombus formation in a flow chamber model, showed that PAR4 inhibition produced a marked decrease in procoagulant platelet formation, whereas inhibition of PAR1 had the opposite effect (French et al., 2016).

\subsubsection{PAR1 and PAR4 as therapeutic targets}

While academia was busy contemplating the issues described above, pharmaceutical companies initiated a race to develop different PAR inhibitors for the treatment of cardiovascular disease, the most famous example being the PAR1 inhibitor vorapaxar, which was approved in 2014 for use in the USA, Canada and the European Union for preventing the recurrence of atherothrombotic events in patients with a history of myocardial infarction or peripheral arterial disease (FDA, 2014). Despite being approved, use of vorapaxar has been severely limited due to the high incidence of bleeding events in patients when treated with vorapaxar in conjunction with ASA and/or P2Y12 inhibitors such as clopidogrel (Gao et al., 2015). More recently, preclinical studies using a primate stroke model have suggested that inhibition of PAR4 might result in an equally potent protection from stroke, but could result in a reduced risk of bleeding in comparison with PAR1 inhibition (Wong et al., 2016). 


\subsection{How thrombin makes use of its exosites to activate PAR4 (Paper I, unpublished work)}

My work in this area started with an idea from a previous, ultimately failed project, during which it was observed that maximal platelet fibrinogen binding was substantially higher upon PAR4 activation with saturating concentrations of the hexapeptide AYPGKF (PAR4-AP), a specific PAR4 agonist, than with SFLLRN (PAR1-AP), a hexapeptide-agonist specific for PAR1-AP. As one major methodological problem hampering progress in the study of PAR activation by thrombin at the time was the inability to distinguish the contributions of PAR1 and PAR4 to thrombin-induced platelet activation, we wanted to examine whether we could construct an assay wherein this observed difference in maximal fibrinogen binding could be used as a tool to separate the effects of activation of the respective receptor, without the use of unreliable inhibitors or desensitization techniques with unknown consequences for platelet function.

The applicability of this approach was confirmed using a novel flow cytometric assay in which the IgM antibody PAC-1, which selectively binds to the fibrinogen receptor GpIIb/IIIa when it has undergone a structural transition into a fibrinogen-binding configuration (Shattil et al., 1985), was used as a surrogate marker for fibrinogen binding. The tetrapeptide GPRP was used to prevent fibrinogen polymerization (Michelson, 1994). Our assay involved titration of $\alpha$-thrombin with or without a saturating concentration of PAR1-AP to separate the PAR4-component of thrombin-induced platelet activation. In accordance with the studies by Leger (Leger et al., 2006) and $\mathrm{Wu}$ (Wu et al., 2003) described above, we found that thrombin-induced platelet activation via PAR4 is evident at much lower concentrations than those reported for recombinant systems.

We then proceeded by examining the importance of the high affinity binding sites (exosite I and II) on thrombin for thrombin-induced PAR4 activation. These recognition sites have been found to be critical for determining thrombin substrate specificity for different coagulation factors (Bukys et al., 2006; Segers et al., 2007), but little was previously known regarding the potential roles of exosite I and II for PAR4 activation. To probe the contribution of exosite I and II in thrombin cleavage of the respective PAR receptor isoforms, we used the DNA aptamers HD1 and HD22, which have been shown to specifically bind to and inhibit interaction of exosite I and II, respectively (Kretz et al., 2006). 
When applying these aptamers to our new assay described above, it was evident that blockage of exosite II produced a profound inihibition of PAR4 cleavage. These results were confirmed using measurements of intracellular calcium, where it was shown that addition of HD22 shifted the intracellular calcium profile of thrombin-induced platelet activation to mimic that of platelet stimulation with PAR1-AP, whereas addition of HD1 produced a prolonged calcium transient consistent with that of platelet activation via PAR4. Our results were also confirmed with western blot using the monoclonal antibody $5 \mathrm{~F} 4$ to visualize PAR4 and densitometry to quantify differences in receptor band density. To exclude the possibility of unspecific interactions between the relatively large aptamer HD22 and thrombin as a cause for the observed inhibitory effect, we also confirmed the observed dependency on HD22 for thrombin-induced platelet activation via PAR4 using heparin, a molecule known to bind to exosite II on thrombin (Li et al., 2004).

Lastly, we wanted to explore the role of GpIba as a potential cofactor for PAR4, as it is known that GpIba binds to exosite II with high affinity (Ruggeri et al., 2010), an interaction previously shown to facilitate thrombin-induced activation of PAR1 (De Candia et al., 2001). Using the snake venom NK protease, which cleaves off the extracellular, exosite II-binding domains of GpIba (Wijeyewickrema et al., 2007), as well as SZ2, a monoclonal antibody which has been shown to block the exosite II-binding domains of GpIba (Adam et al., 2003), we could show that PAR4 activation was not significantly affected by blockage of this interaction, suggesting that the exosite II-dependency of thrombin-induced PAR4 activation was not dependent on GpIba. Also, in contrast to HD22, treatment with NK protease or addition of SZ2 did not inhibit cleavage of PAR4 by $\mathrm{Y}$-thrombin, a proteolytic degradation product of $\alpha$-thrombin unable to activate PAR1 due to a lack of exosite I but which retains exosite II and the ability to activate PAR4 (Soslau et al., 2001, 2004). Taken together, our results imply that exosite II is critical for thrombin-induced platelet activation via PAR4, and further that this observed dependency on exosite II cannot be attributed to the previously known interaction between exosite II and GpIba.

Although these result were unexpected and to some extent contradict the dominating concept that PAR4 activation is facilitated exclusively by local interactions between PAR4 and residues in the vicinity of the active site of thrombin (Jacques and Kuliopulos, 2003), indirect support for our findings 
could be inferred from previous studies. For example, our findings could help to explain the observation by Wu and colleagues that YD-3, a selective inhibitor of PAR4, did not increase the inhibitory effect of HD22 on thrombin-induced platelet activation, while producing a synergistic inhibition in combination with the exosite I inhibitor HD1 (Wu et al., 2011). Our results can also shed new light on the finding that mutations in W215, a residue located close to exosite II in thrombin, dramatically reduces the ability of thrombin to cleave PAR4 in a recombinant cell model (Ayala et al., 2001).

The notion that PAR4 activation by thrombin is strongly inhibited upon blockade of exosite II provides new insights into how thrombin-induced platelet activation can be modulated in order to fine tune the platelet response to thrombin generation in various scenarios. Our findings suggest that serpins, an endogenous superfamily of proteins that inhibit thrombin by interacting with exosite II (Li et al., 2010a), could be expected to preferentially inhibit PAR4 activation and that exosite II inhibition could be a feasible strategy for targeting PAR4 in pharmacological interventions. To further explore this notion, we have performed studies on the effects of heparins on thrombin-induced platelet activation via PAR1 and PAR4, with or without the serpin antithrombin. Our results indicate that heparin-antithrombin has differential effects on thrombin-induced platelet activation via PAR1 and PAR4, completely blocking PAR4 activation while having only a modest effect on PAR1-mediated platelet activation in the presence of high concentrations of thrombin (Figure 10 \& 11) 


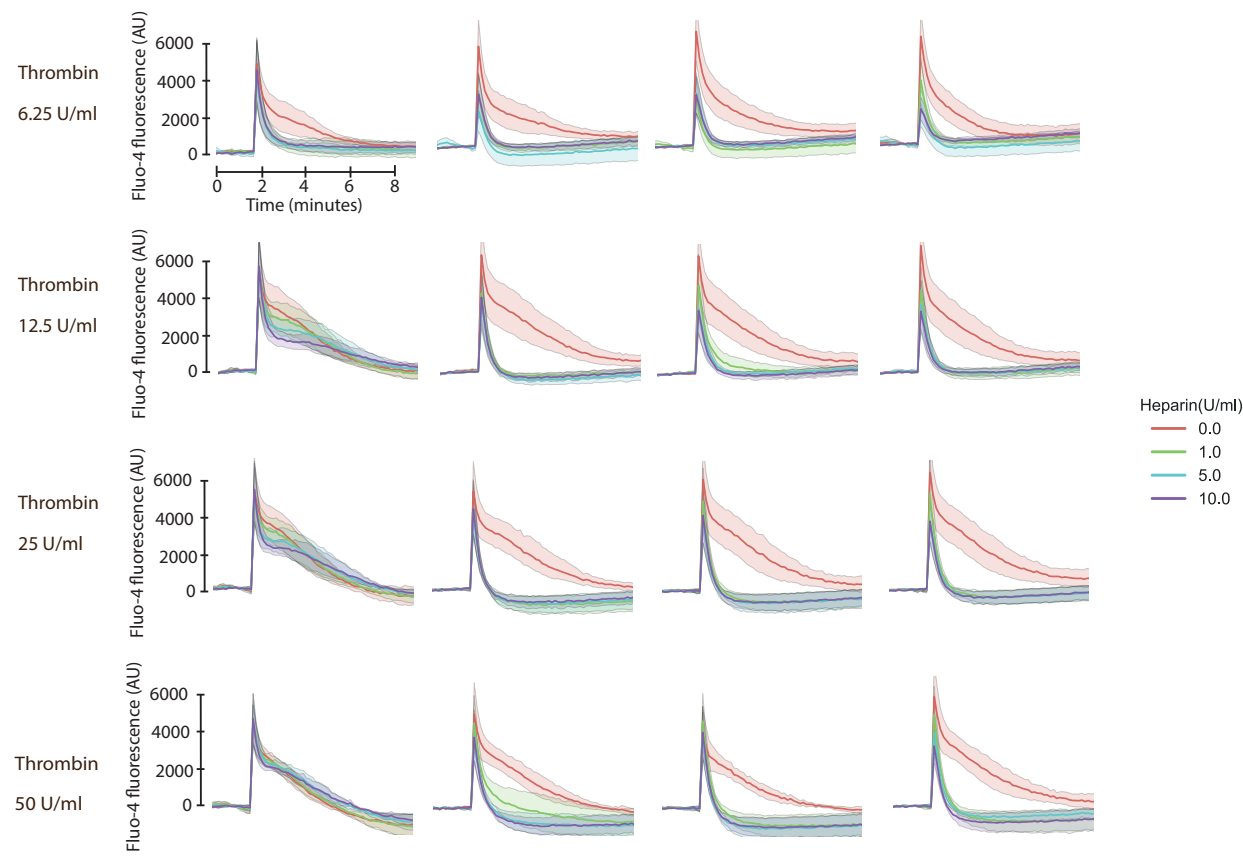

Figure 10. Heparin + antithrombin cause complete inhibition of sustained calcium mobilization induced by thrombin. Intracellular calcium mobilization in washed platelets exposed to varying concentrations of thrombin, unfractionated heparin and antithrombin. Concentrations are given as $U / \mathrm{ml}$ for thrombin and heparin and IU/ $\mathrm{ml}$ for antithrombin. Note that heparin alone is sufficient to block sustained calcium mobilization associated with PAR4 activation at "low" thrombin concentrations, but have no impact on the calcium "spike" associated with PAR1 activation. Antithrombin alone has very little impact on thrombin-induced calcium mobilization. When added in combination, it is sufficient with heparin concentrations in the range used for treatment of venous thromboembolism (1 $\mathrm{U} / \mathrm{ml}$ ) and antithrombin levels as low as in the range observed during coagulopathies such as disseminated intravascular coagulation (DIC) $(0.3 \mathrm{IU} / \mathrm{ml})$ to obtain a complete inhibition of sustained calcium mobilization. In contrast, all tested concentrations of antithrombin and heparin in combination have a negligible to modest impact on the initial calcium spike. Each line represents the average of at least 4 different measurements with shaded areas indicating confidence intervals calculated by boot strapping. 


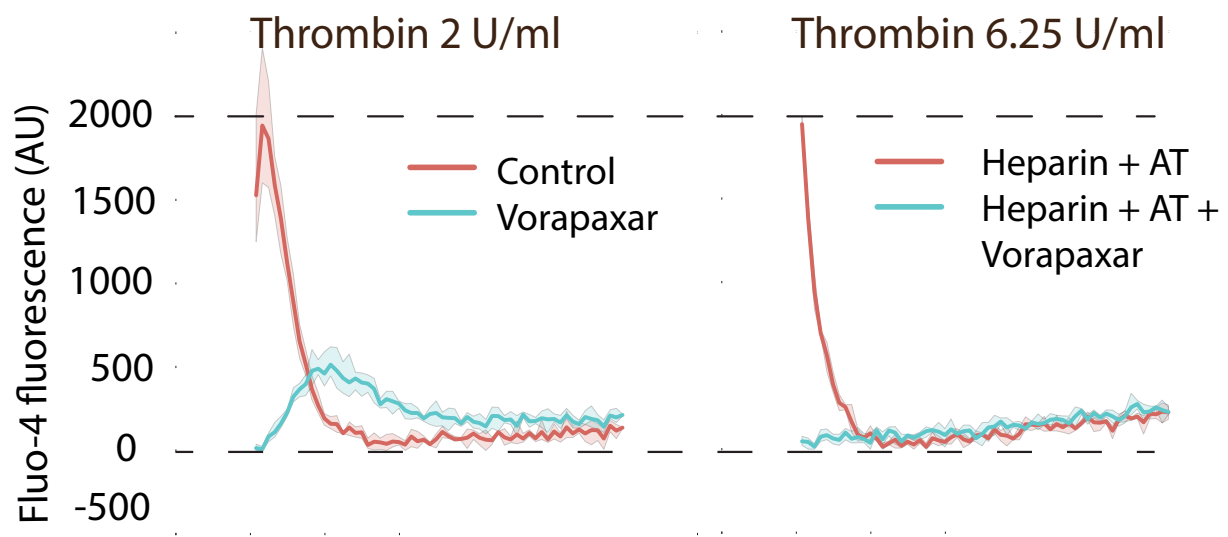

Figure 11. Selective inhibition of thrombin-induced PAR4 activation by heparin+antithrombin. To compare the contribution of PAR1 and PAR4 to thrombin-induced platelet activation in the presence or absence of heparin+antithrombin, we selected thrombin concentrations that produced an equal peak calcium signal when added to platelets alone and in the presence of heparin and antithrombin (AT) (2 $U$ and $6.25 U$, respectively). Inhibition of PAR1 activation with vorapaxar alone resulted in residual prolonged platelet calcium mobilization with a calcium profile resembling PAR4 activation, while a combination of vorapaxar with heparin/antithrombin completely blocked calcium mobilization, indicating that heparin/antithrombin preferentially inhibit PAR4 activation.

As the above findings obviously fall very short of answering any of the "big" questions formulated in the beginning of this chapter, I have continued working with thrombin-induced platelet activation via the PAR receptors in various projects. One hypothesis we have explored is that a dual thrombin receptor configuration could provide a mechanism for sustaining platelet reactivity in the thrombus shell, where the slow leakage of subnanomolar concentrations of thrombin from the core of the thrombus will lead to PAR receptor desensitization. A second set of PARs could then function as an "extra gear" in the event of re-bleeding or thrombus instability, as the resulting thrombin generation would result in concentrations sufficient to provoke a robust response from one of the receptors even when the other is completely desensitized. Since this concept would require different gradient-dependencies of PAR1 and PAR4 activation, we have designed a pump-controlled agonist infusion system to assess the response of PAR1 and PAR4 to different agonist gradients, as measured using aggregometry, flow cytometry (marker P-selectin) or calcium mobilization experiments. Using 
an algorithm-based experimental protocol to avoid bias when selecting experimental parameters, we have characterized the gradient-dependence of GPCR signaling via PAR1, PAR4, P2Y12 and TPa in platelets. Our results clearly show that PAR4 reactivity measured with LTA can be sustained in the presence of low agonist concentration gradients, whereas PAR1 signaling quickly wanes when agonists are infused over a period of more than 100 sec (Figure $12 \& 13$ ). The generalizability of these results on other aspects of platelet activation were confirmed using flow cytometry to measure granule secretion (P-selectin exposure) and measurements of intracellular calcium (data not shown).

A) Infusion of agonist concentration gradients, experimental setup

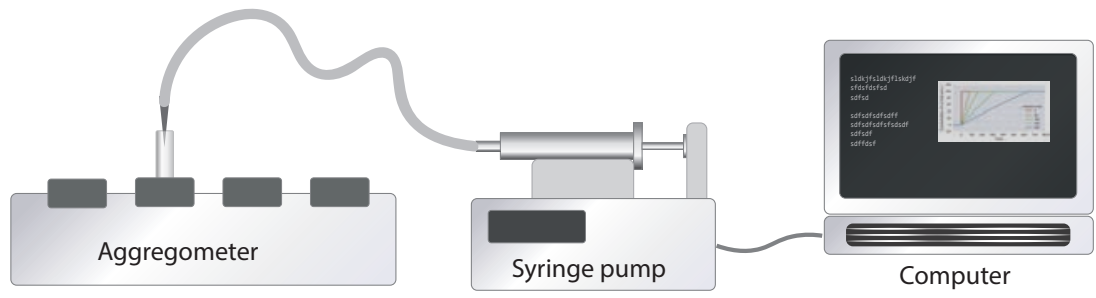

B) Concentration gradients

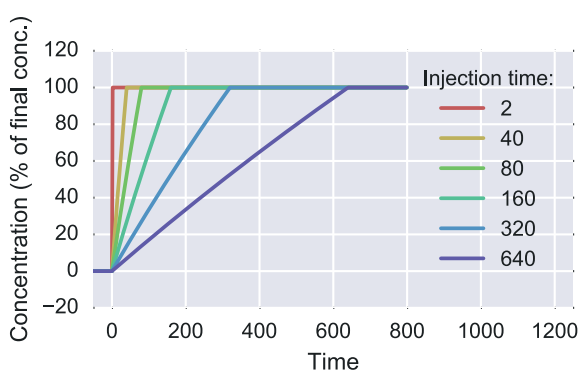

C) Platelet aggregation response

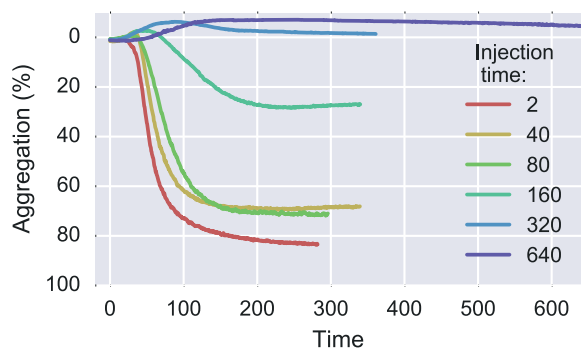

Figure 12: Instrumental setup and read-out in the pump-controlled infusion system used to assess desensitization of platelet receptors upon exposure to constant agonist gradients. 
A)

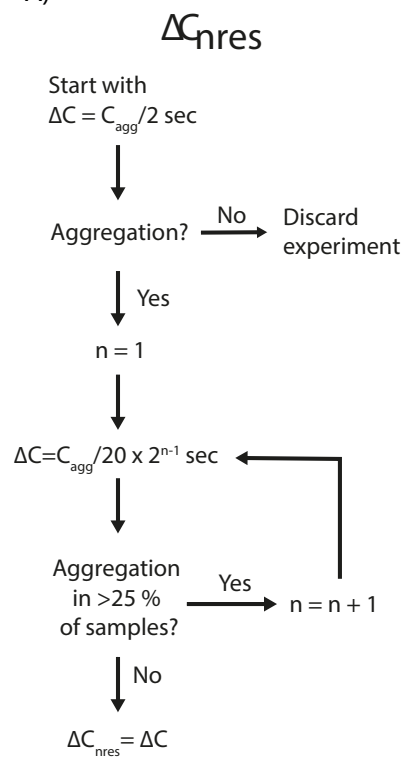

B)

Agonist:

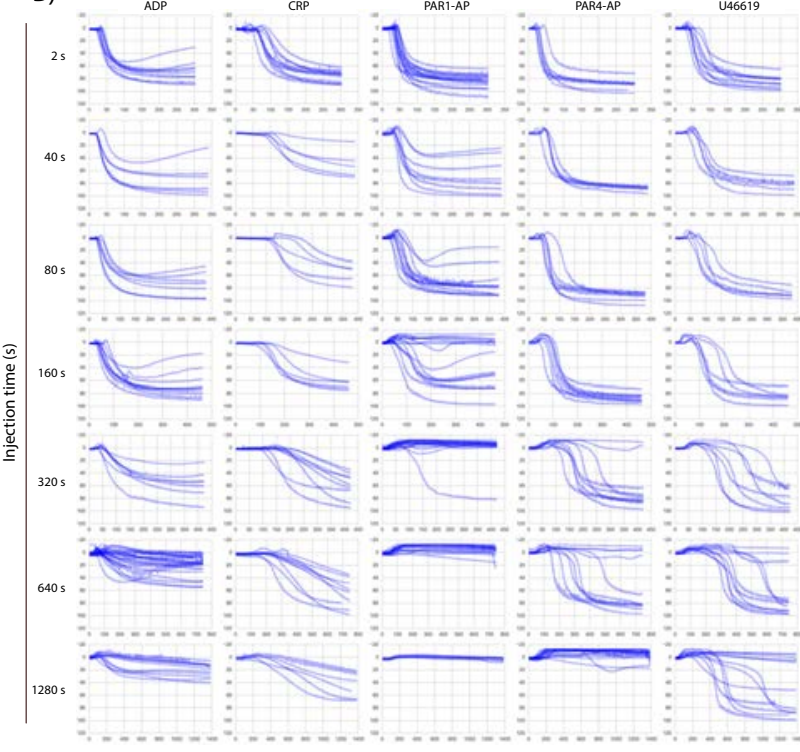

C)

Aggregation paramterers

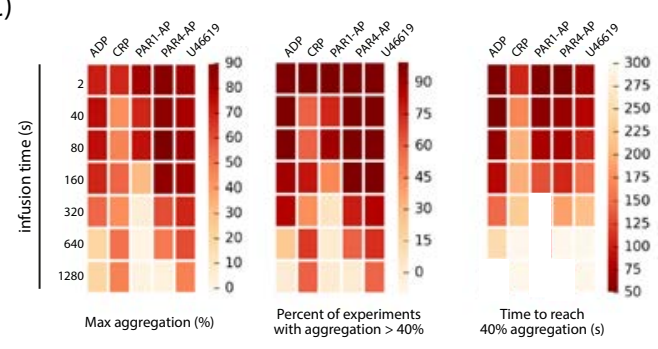

D)

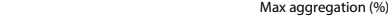

CRP

PAR1-AP

PAR4-AP

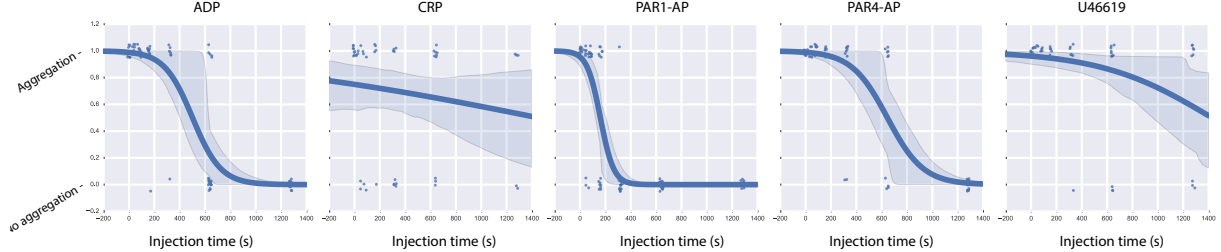

Figure 13: An algorithm-based protocol (A) was used to systematically assess desensitization of PAR1, PAR4, P2Y12, TPa and GPVI when exposed to temporal agonist gradients. $C_{\text {agg }}$ is the minimal concentration required to give $>75 \%$ aggregation in 4 consecutive samples. Aggregometry $(B-C)$ revealed prominent desensitization of PAR1 when the infusion time was $>80 \mathrm{sec}$, whereas aggregation was still maintained for PAR4 at an infusion time of $640 \mathrm{sec}$. Using logistic regression (D), we could determine a temporal equivalent to IC5O of $151 \mathrm{sec}$ for PAR1 and $607 \mathrm{sec}$ for PAR4. 


\section{Platelets in the coagulation cas- cade: amplifiers, initiators or both?}

\subsection{Platelets and coagulation factors: the yin and yang of hemostasis}

The intimate relationship between platelets and fibrin formation have been apparent since the first pioneering microscopic investigations of blood clots by the likes of William Addison and Giulio Bizzozero in the $19^{\text {th }}$ century. Mistakenly believing that the "great number of extremely minute molecules or granules" observed on the surface of fibrins clot were fragmented leukocytes and not the unknown blood cell we now call platelets, Addison described that "Whilst examining these minute bodies, I observed the coagulation of the fibrin commence" (Addison, 1842). Although this observation clearly implies an active role for platelets in the formation of fibrin fibers, mechanistic insights into how platelets contribute to coagulation required a detailed understanding of the coagulation cascade, knowledge still more than a century in the making. As described in section 2.3.1., current models of coagulation ascribe important roles for platelets as amplifiers of coagulation, but the question of whether platelets could initiate coagulation remains controversial (Geddings and Mackman, 2014). Two recently proposed mechanisms whereby platelets could initiate coagulation have been explored in paper II-IV of this thesis.

\subsection{Platelets as initiators of contact activation (Papers II and III)}

Although the revised, cell-based model of tissue factor-induced coagulation described in section 2.3.1 is largely consistent with current experimental and epidemiological data regarding hemostasis in humans, the last decades has witnessed the emergence of several lines of experimental evidence in support of a possible role for the contact activation pathway of coagulation in thrombosis. For example, one strain of factor XII (FXII)-deficient mice have been shown to be protected from thrombosis in multiple murine in vivo models of thrombosis (Cheng et al., 2010; Kleinschnitz et al., 2006; Renne et al., 2005) and inhibition of FXII has been shown to protect from 
arterial thrombosis in mice (Decrem et al., 2009; Hagedorn et al., 2010; Revenko et al., 2011).

The above investigations formed the theoretical incentive for a plethora of experimental studies identifying possible initiators of contact activation in various thrombotic conditions (von Brühl et al., 2012; Maas et al., 2008; van der Meijden et al., 2009). One theory gaining particular popularity was the claim that platelet-derived polyphosphates released from dense granules cause thrombosis by activating FXII, thereby initiating the intrinsic pathway of coagulation (Kenne et al., 2015; Müller et al., 2009; Renné et al., 2012). If correct, this notion would signify a major conceptual transition in our understanding of hemostatic regulation in mammals, possibly with as far-reaching consequences for the "yin and yang of hemostasis" as the finding that thrombin activates platelets one century earlier.

Polyphosphates are linear polymers in which phosphate moieties are connected by phosphoanhydride bonds (Kornberg, 1995). Originally discovered in bacteria, polyphosphates were unexpectedly also identified as components of platelet dense granules in 2004 (Ruiz et al., 2004). In 2006, a study reported that polyphosphates with a chain length of approximately 75 produced a FXII-dependent shortening of the clotting time of recalcified plasma, providing the first experimental evidence supporting a role for polyphosphates in the initiation of contact activation (Smith et al., 2006). In an article published 2009 (hereinafter called paper A), the concept of polyphosphates as "a long sought link between primary and secondary hemostasis" was pushed one step further with the presentation of experimental results implying that the acceleration of coagulation observed when activating platelets was entirely dependent on contact activation by platelet polyphosphates, that lethal pulmonary embolism could be provoked in mice by activating mouse platelets with PAR1-AP, and that challenged mice could be salvaged by concomitant infusion of phosphatases that degrade polyphosphates (Müller et al., 2009).

Intrigued by this new development, we set out to replicate and build on the experiments presented as proof for the claim that platelets activate factor XII in paper A. Unexpectedly, our results presented in paper II indicated that the key findings supporting a role for platelet-derived 
polyphosphates in FXII activation were irreproducible. Using a chromogenic substrate to probe for FXIIa activity, we found that platelet-derived polyphosphates were very weak activators of FXII and that stimulation of platelets with various agonists did not result in detectable FXIIa generation. Upon pre-incubation with platelet agonists, platelet-dependent shortening of spontaneous clotting times of recalcified plasma were found to be unrelated to contact activation, but highly dependent on the exposure of phosphatidylserine-containing procoagulant membranes.

Likewise, preincubation with phosphatases or corn trypsin inhibitor which are known to degrade polyphosphates or inactivate FXIIa, respectively, did not reverse the reduction of clotting times observed when pre-activating platelets, providing further proof for that the procoagulant effect of platelets is unrelated to the generation of FXIIa. Interestingly, we found that the experimental system used to verify the original results claiming a role for FXII in platelet procoagulant activity was heavily influenced by artificial contact activation, probably stemming from the use of a moving metal ball to detect clotting, which could partially explain the discrepant results.

Most disturbingly, major difficulties were encountered when trying to reproduce the experiments conducted to prove the hypothesis of platelet-dependent activation of FXII as a thrombogenic mechanism in vivo. Firstly, the finding that PAR1-AP could provoke lethal pulmonary embolism in mice was inconsistent with the literature, as previous studies have shown that PAR1, the receptor responsive to stimulation with the agonist peptide PAR1-AP, is not expressed on murine platelets (Connolly et al., 1996; Derian et al., 1995). In an attempt to reproduce the experiments reported in the original article, we found that mice exposed to PAR1-AP in up to ten times higher doses than those reported in the original study did not result in any signs of thromboembolic disease or pathological stress in challenged animals. Also, when trying to dissolve the polyphosphate preparation used in the original publication, we found that the solubility of the substance did not permit infusion of the stated amounts of polyphosphates into mice without precipitation of large solid particles.

The publication of the above negative findings in 2013 (Paper II) were followed by two separate responses by different authors of paper A, wherein the following issues were raised regarding possible confounding factors supposedly explaining our discrepant results in vitro (Nickel et al., 2013): 
1. It was claimed that the low FXII-activating capacity of the polyphosphate preparations used in our paper was due to time-dependent degradation, the authors stating that polyphosphates were known to be degraded within a matter of months despite being stored in $-70^{\circ} \mathrm{C}$;

2. The specificity of the fluorogenic substrate used for measuring FXIIa activity was questioned, the authors claiming that the substrate could also be activated by a number of other proteases;

3. The use of tissue factor in one assay to eliminate the influence of artificial contact activation emanating from interfaces where blood was exposed to foreign surfaces (Grunkemeier et al., 1998; van der Kamp and van Oeveren, 1994; van Oeveren et al., 2002) was criticized, the authors claiming that this procedure would mask contact activation by polyphosphates;

4. It was claimed that our own results showing a slight reduction in clotting times of recalcified plasma upon preincubation with platelet agonists were inconsistent with a previous publication from our laboratory, wherein a more pronounced effect on of clotting times was reported (Ramström et al., 2003); and finally

5. Questions were raised regarding the assumed use of a particular filter that was claimed to induce contact activation. Remarkably, no mention was made of our questions regarding the validity of the animal experiments presented in paper $\mathrm{A}$.

As the critique formulated in the above responses to Paper II was based on a number of errors and unfounded assumptions, we published a "response to the response" (Paper III) with new experimental evidence further validating the findings in Paper II. In summary, the following issues were clarified:

1. The activity measurements on our sample of platelet-derived polyphosphates obtained from the authors of paper A was performed within 1.5 months after receiving the substances, with a sizeable margin of time before a substantial portion of the polyphosphates could be expected to be degraded;

2. The claim that our results obtained using a chromogenic FXIIa substrate were influenced by unspecific reactions with other proteases were shown to be logically invalid;

3. We presented data showing that our assay involving the use of a small amount of tissue factor to eliminate the influence of artificial contact 
activation was still ten times more sensitive to non-artefactual contact activation than the assay used in paper $\mathrm{A}$;

4. The apparent discrepancy between the results presented in Paper II and a previous article from our group was evidently caused by different experimental conditions, as tissue factor was used in paper II whereas no exogenous initiator of coagulation was added in the previous publication (Ramström et al., 2003); and that

5. The critique regarding the alleged use of filters which activate the contact pathway was unfounded as we did not use the type of filter described in the response (Nickel et al., 2013), and could show that the filter we used for the above experiments did not generate detectable amounts of FXIIa.

In the aftermath of this ordeal, the scientific debate regarding the role of polyphosphates in hemostasis has shifted somewhat, with more attention directed on other effects of platelet-derived polyphosphates on other components of the coagulation system as opposed to their supposed effects on contact activation (Choi et al., 2015; Geng et al., 2013). Regarding the role of FXII in thrombus formation and propagation, recently published data suggest that procoagulant platelet membranes have FXIIa generating activity, whereas dense granule release was found to have inhibitory effects on FXIIa generation (Zakharova et al., 2015).

Using a flow chamber-based in vitro thrombosis model, a recent study co-authored by one of the originators of paper A found evidence for "a role for polyP distinct from FXIIa activation and requiring low extrinsic pathway participation" (Zhu et al., 2015). To this date, the pathophysiological role of contact activation in thrombotic disorders remain unclear (Gailani et al., 2015). Epidemiological data on the incidence of thromboembolic complications in individuals with FXII deficiency is limited, but published studies on the matter seem to contradict the concept of platelet-dependent contact activation as a patophysiologically relevant cause of thrombosis, reporting a "normal" occurrence of deep vein thrombosis (Koster et al., 1994) in the studied cohorts. Also, elevated levels of FXII were not associated with a higher incidence of thrombosis in a recent longitudinal study involving a large number of participants (Cushman et al., 2009). In contrast, clinical evidence supporting a role for FXIa in thrombosis is growing (Cushman et al., 2009), and it was recently shown that translational suppression of FXI using FXI antisense oligonucleotides does not provoke bleeding and is protective against thrombosis in humans after total knee arthroplasty (Buller 
et al., 2015), verifying the concept that inhibition of FXIa could prevent thrombosis while having a small impact on bleeding risk.

\subsection{Platelets, microparticles and tissue factor (Paper IV]}

The notion that blood components contain platelet-derived subcellular particles that promote coagulation can be traced back to the 1960s, when it was found that ultracentrifugation of platelet-poor plasma rendered blood less prone to coagulate, leaving the researchers to conclude that blood contains an additional procoagulant factor (Wolf, 1967). In subsequent studies, this factor was identified as lipid vesicles mainly originating from platelets and megakaryocytes. Platelet microparticles (PMP) are small (o.o3-1.o $\mu \mathrm{m})$ cytoplasmic fragments which are released from platelets upon activation (Heijnen et al., 1999), physical stress (Miyazaki et al., 1996) and storage (Bode et al., 1991). Importantly, release of PMPs from resting platelets is virtually non-existent (van der Zee et al., 2006), making PMPs interesting as markers for various cardiovascular conditions characterized by platelet activation.

Although it was previously known that microparticles are indispensable for "spontaneous" clotting of recalcified plasma, the finding that tissue factor can be transferred in vitro from monocytes to PMPs via membrane fusion (Del Conde et al., 2005) conjured up the possibility that PMPs could initiate thrombosis single-handedly, spurring a flurry of renewed interest for PMPs as potential causative agents of thrombosis. However, a major barrier to exploring this promising theme in large clinical trials is the lack of a precise and practical method for quantifying the presence of tissue factor-exposing microparticles (TFMP) in clinical samples (van Es et al., 2015). As tissue factor can be expressed in distinct forms with radically different procoagulant activity (Diamant et al., 2002), such an assay would preferably be based on the functional activity of TFMPs, rather than on antigen binding.

In this context, thrombin generation (TG) measurements were introduced as an alternative method for functional quantification of the tissue factor-dependent procoagulant activity of PMPs. A commercial kit with a reagent containing $4 \mu \mathrm{M}$ phospholipids was designed to allow for such measurements without the need for labor-intense techniques such as flow cytometry (Thrombinoscope $®$, Maastricht, the Netherlands). However, when 
evaluating this kit, we found that the addition of phospholipids rendered samples extremely sensitive for artefactual contact activation, in line with previous observations that contact activation is amplified in the presence of phospholipid membranes (Ollivier et al., 2010). Failure to account for this possible confounder could easily lead to erroneous interpretations and overestimations of TFMP content. In our discussion, we present different feasible strategies for improving the analytical precision of TG-based approaches to quantify TFMP content, e.g. by adding corn trypsin inhibitor (CTI) or by introducing control experiments in which antibodies directed towards TF are used to quantify the contribution of TF to the analytical endpoint (Khorana et al., 2008; Tesselaar et al., 2007). Yet another cost-effective approach which could be feasible for larger clinical trials would be to isolate microparticles before adding them to CTI-treated normal plasma (Aleman et al., 2011; Bidot et al., 2008). 


\subsection{References}

Adam, F., Guillin, M.-C., and Jandrot-Perrus, M. (2003). Glycoprotein Ib-mediated platelet activation. A signalling pathway triggered by thrombin. Eur. J. Biochem. 270, 2959-2970.

Addison, W. (1842). On the colourless corpuscles and on the molecules and cytoblasts in the blood. London Med Gaz NS 30, 144-152.

Ahn, H.-S., Arik, L., Boykow, G., Burnett, D.A., Caplen, M.A., Czarniecki, M., Domalski, M.S., Foster, C., Manna, M., Stamford, A.W., et al. (1999). Structure-activity relationships of pyrroloquinazolines as thrombin receptor antagonists. Bioorg. Med. Chem. Lett. 9, 2073-2078.

Aird, W.C. (2003). Hemostasis and irreducible complexity. J. Thromb. Haemost. 1, 227-230.

Albanyan, A.-M., Murphy, M.F., Rasmussen, J.T., Heegaard, C.W., and Harrison, P. (2009). Measurement of phosphatidylserine exposure during storage of platelet concentrates using the novel probe lactadherin: a comparison study with annexin V. Transfusion 49, 99-107.

Aleman, M.M., Gardiner, C., Harrison, P., and Wolberg, A.S. (2011). Differential contributions of monocyte- and platelet-derived microparticles towards thrombin generation and fibrin formation and stability. J. Thromb. Haemost. 9, 2251-2261.

Andrade-Gordon, P., Maryanoff, B.E., Derian, C.K., Zhang, H.C., Addo, M.F., Darrow, A.L., Eckardt, A.J., Hoekstra, W.J., McComsey, D.F., Oksenberg, D., et al. (1999). Design, synthesis, and biological characterization of a peptide-mimetic antagonist for a tethered-ligand receptor. Proc. Natl. Acad. Sci. U. S. A. 96, 12257-12262.

Andree, H.A., Reutelingsperger, C.P., Hauptmann, R., Hemker, H.C., Hermens, W.T., and Willems, G.M. (1990). Binding of vascular anticoagulant alpha (VAC alpha) to planar phospholipid bilayers. J. Biol. Chem. 265, 4923-4928.

Arachiche, A., Mumaw, M.M., De La Fuente, M., and Nieman, M.T. (2013). Protease-activated receptor 1 (PAR1) and PAR4 heterodimers are required for PAR1-enhanced cleavage of PAR4 by a-thrombin. J. Biol. Chem. 288, $32553-32562$. 
Ayala, Y.M., Arosio, D., and Di Cera, E. (2001). Mutation of W215 compromises thrombin cleavage of fibrinogen, but not of PAR1 or protein C. Ann. N. Y. Acad. Sci. 936, 456-458.

Azuma, H., Ishikawa, M., and Sekizaki, S. (1986). Endothelium-dependent inhibition of platelet aggregation. Br. J. Pharmacol. 88, 411-415.

Bajzar, L., Manuel, R., and Nesheim, M.E. (1995). Purification and characterization of TAFI, a thrombin-activable fibrinolysis inhibitor. J. Biol. Chem. 270, 14477-14484.

Bauer, K.A., Kass, B.L., ten Cate, H., Hawiger, J.J., and Rosenberg, R.D. (1990). Factor IX is activated in vivo by the tissue factor mechanism. Blood $76,731-736$.

Becker, R.P., and De Bruyn, P.P. (1976). The transmural passage of blood cells into myeloid sinusoids and the entry of platelets into the sinusoidal circulation; a scanning electron microscopic investigation. Am. J. Anat. 145, 183-205.

Bennett, J.S. (2015). Regulation of integrins in platelets. Biopolymers 104, 323-333.

Berny, M.A., Munnix, I.C.A., Auger, J.M., Schols, S.E.M., Cosemans, J.M.E.M., Panizzi, P., Bock, P.E., Watson, S.P., McCarty, O.J.T., and Heemskerk, J.W.M. (2010). Spatial Distribution of Factor Xa, Thrombin, and Fibrin(ogen) on Thrombi at Venous Shear. PLoS One 5, e10415.

Berridge, M.J., Bootman, M.D., and Roderick, H.L. (2003). Calcium signalling: dynamics, homeostasis and remodelling. Nat. Rev. Mol. Cell Biol. 4, 517-529.

Bidot, L., Jy, W., Bidot, C.J., Jimenez, J.J., Fontana, V., Horstman, L.L., and Ahn, Y.S. (2008). Microparticle-mediated thrombin generation assay: increased activity in patients with recurrent thrombosis. J. Thromb. Haemost. 6, 913-919.

Bode, A.P., Orton, S.M., Frye, M.J., and Udis, B.J. (1991). Vesiculation of platelets during in vitro aging. Blood 77, 887-895.

Bohls, R.L., Smith, R., Ferro, P.J., Silvy, N.J., Li, Z., and Collisson, E.W. (2006). The use of flow cytometry to discriminate avian lymphocytes from contaminating thrombocytes. Dev. Comp. Immunol. 30, 843-850.

Brass, L., and Wannemacher, K. (2011). Regulating thrombus growth and stability to achieve an optimal response to injury. J. Thromb. Haemost. 9, 66-75. 
Brass, L.F., and Diamond, S.L. (2016). Transport physics and biorheology in the setting of hemostasis and thrombosis. J. Thromb. Haemost. 14, 906-17.

Braun, A., Varga-Szabo, D., Kleinschnitz, C., Pleines, I., Bender, M., Austinat, M., Bosl, M., Stoll, G., and Nieswandt, B. (2009). Orai1 (CRACM1) is the platelet SOC channel and essential for pathological thrombus formation. Blood 113, 2056-2063.

Briede, J.J., Heemskerk, J.W., van't Veer, C., Hemker, H.C., and Lindhout, T. (2001). Contribution of platelet-derived factor Va to thrombin generation on immobilized collagen- and fibrinogen-adherent platelets. Thromb. Haemost. 85, 509-513.

von Brühl, M.-L., Stark, K., Steinhart, A., Chandraratne, S., Konrad, I., Lorenz, M., Khandoga, A., Tirniceriu, A., Coletti, R., Köllnberger, M., et al. (2012). Monocytes, neutrophils, and platelets cooperate to initiate and propagate venous thrombosis in mice in vivo. J. Exp. Med. 209, 819-835.

Bukys, M.A., Orban, T., Kim, P.Y., Beck, D.O., Nesheim, M.E., and Kalafatis, M. (2006). The structural integrity of anion binding exosite I of thrombin is required and sufficient for timely cleavage and activation of factor $\mathrm{V}$ and factor VIII. J. Biol. Chem. 281, 18569-18580.

Buller, H.R., Bethune, C., Bhanot, S., Gailani, D., Monia, B.P., Raskob, G.E., Segers, A., Verhamme, P., and Weitz, J.I. (2015). Factor XI antisense oligonucleotide for prevention of venous thrombosis. N. Engl. J. Med. 372, 232-240.

Bye, A.P., Unsworth, A.J., and Gibbins, J.M. (2016). Platelet signaling: a complex interplay between inhibitory and activatory networks. J. Thromb. Haemost. 14, 918-30.

Caen, J., and Wu, Q. (2010). Hageman factor, platelets and polyphosphates: early history and recent connection. J. Thromb. Haemost. 8, 1670-1674.

De Candia, E., Hall, S.W., Rutella, S., Landolfi, R., Andrews, R.K., and De Cristofaro, R. (2001). Binding of thrombin to glycoprotein Ib accelerates the hydrolysis of Par-1 on intact platelets. J. Biol. Chem. 276, 4692-4698.

De Caterina, R., Husted, S., Wallentin, L., Andreotti, F., Arnesen, H., Bachmann, F., Baigent, C., Huber, K., Jespersen, J., Kristensen, S.D., et al. (2013). General mechanisms of coagulation and targets of anticoagulants (Section I): Position paper of the ESC Working Group on Thrombosis - Task Force on anticoagulants in heart disease. Thromb. Haemost. 109, 569-579.

Di Cera, E. (2008). Thrombin. Mol. Aspects Med. 29, 203-254. 
Chen, H., Locke, D., Liu, Y., Liu, C., and Kahn, M.L. (2002). The platelet receptor GPVI mediates both adhesion and signaling responses to collagen in a receptor density-dependent fashion. J. Biol. Chem. 277, 3011-3019.

Chen, J., Ishii, M., Wang, L., Ishii, K., and Coughlin, S.R. (1994). Thrombin receptor activation. Confirmation of the intramolecular tethered liganding hypothesis and discovery of an alternative intermolecular liganding mode. J. Biol. Chem. 269, 16041-16045.

Cheng, Q., Tucker, E.I., Pine, M.S., Sisler, I., Matafonov, A., Sun, M.-F., White-Adams, T.C., Smith, S.A., Hanson, S.R., McCarty, O.J.T., et al. (2010). A role for factor XIIa-mediated factor XI activation in thrombus formation in vivo. Blood 116, 3981-3989.

Choi, S.H., Smith, S.A., and Morrissey, J.H. (2015). Polyphosphate accelerates factor V activation by factor XIa. Thromb. Haemost. 113, 599-604.

Cochrane, C.G., Revak, S.D., and Wuepper, K.D. (1973). Activation of Hageman factor in solid and fluid phases. A critical role of kallikrein. J. Exp. Med. 138, 1564-1583.

Coller, B.S., and Shattil, S.J. (2008). The GPIIb/IIIa (integrin \{alpha\} IIb\{beta\}3) odyssey: a technology-driven saga of a receptor with twists, turns, and even a bend. Blood 112, 3011-3025.

Del Conde, I., Shrimpton, C.N., Thiagarajan, P., and Lopez, J.A. (2005). Tissue-factor-bearing microvesicles arise from lipid rafts and fuse with activated platelets to initiate coagulation. Blood 106, 1604-1611.

Connolly, A.J., Ishihara, H., Kahn, M.L., Farese, R.V.J., and Coughlin, S.R. (1996). Role of the thrombin receptor in development and evidence for a second receptor. Nature 381, 516-519.

Coppinger, J.A., Cagney, G., Toomey, S., Kislinger, T., Belton, O., McRedmond, J.P., Cahill, D.J., Emili, A., Fitzgerald, D.J., and Maguire, P.B. (2004). Characterization of the proteins released from activated platelets leads to localization of novel platelet proteins in human atherosclerotic lesions. Blood 103, 2096-2104.

Coughlin, S.R. (1999). Protease-activated receptors and platelet function. Thromb Haemost 82, 353-356.

Covic, L., Gresser, A.L., and Kuliopulos, A. (2000). Biphasic kinetics of activation and signaling for PAR1 and PAR4 thrombin receptors in platelets. Biochemistry 39, 5458-5467. 
Cui, J., O'Shea, K.S., Purkayastha, A., Saunders, T.L., and Ginsburg, D. (1996). Fatal haemorrhage and incomplete block to embryogenesis in mice lacking coagulation factor V. Nature 384, 66-68.

Cushman, M., O'Meara, E.S., Folsom, A.R., and Heckbert, S.R. (2009). Coagulation factors IX through XIII and the risk of future venous thrombosis: the Longitudinal Investigation of Thromboembolism Etiology. Blood 114, 2878-2883.

Dachary-Prigent, J., Freyssinet, J.M., Pasquet, J.M., Carron, J.C., and Nurden, A.T. (1993). Annexin V as a probe of aminophospholipid exposure and platelet membrane vesiculation: a flow cytometry study showing a role for free sulfhydryl groups. Blood 81, 2554-2565.

Davey, M.G., and Luscher, E.F. (1967). Actions of thrombin and other coagulant and proteolytic enzymes on blood platelets. Nature 216, 857-858.

Davidson, C.J., Tuddenham, E.G., and McVey, J.H. (2003). 450 Million Years of Hemostasis. J. Thromb. Haemost. 1, 1487-1494.

Davie, E.W., and Ratnoff, O.D. (1964). Waterfall sequece for intrinsic blood clotting. Science 145, 1310-1312.

Dawood, B.B., Lowe, G.C., Lordkipanidzé, M., Bem, D., Daly, M.E., Makris, M., Mumford, A., Wilde, J.T., and Watson, S.P. (2012). Evaluation of participants with suspected heritable platelet function disorders including recommendation and validation of a streamlined agonist panel. Blood 120 , 5041-5049.

Decrem, Y., Rath, G., Blasioli, V., Cauchie, P., Robert, S., Beaufays, J., Frere, J.-M., Feron, O., Dogne, J.-M., Dessy, C., et al. (2009). Ir-CPI, a coagulation contact phase inhibitor from the tick Ixodes ricinus, inhibits thrombus formation without impairing hemostasis. J. Exp. Med. 206, 2381-2395.

Derian, C.K., Santulli, R.J., Tomko, K.A., Haertlein, B.J., and Andrade-Gordon, P. (1995). Species differences in platelet responses to thrombin and SFLLRN. receptor-mediated calcium mobilization and aggregation, and regulation by protein kinases. Thromb. Res. 78, 505-519.

Detwiler, T.C., and Feinman, R.D. (1973). Kinetics of the thrombin-induced release of calcium(II) by platelets. Biochemistry 12, 282-289.

Diamant, M., Nieuwland, R., Pablo, R.F., Sturk, A., Smit, J.W.A., and Radder, J.K. (2002). Elevated numbers of tissue-factor exposing microparticles correlate with components of the metabolic syndrome in uncomplicated type 2 diabetes mellitus. Circulation 106, 2442-2447. 
van Es, N., Bleker, S., Sturk, A., and Nieuwland, R. (2015). Clinical Significance of Tissue Factor-Exposing Microparticles in Arterial and Venous Thrombosis. Semin. Thromb. Hemost. 41, 718-727.

FDA (2014). FDA approves Zontivity to reduce the risk of heart attacks and stroke in high-risk patients.

French, S.L., Arthur, J.F., Lee, H., Nesbitt, W.S., Andrews, R.K., Gardiner, E.E., and Hamilton, J.R. (2016). Inhibition of protease-activated receptor 4 impairs platelet procoagulant activity during thrombus formation in human blood. J. Thromb. Haemost. 14, 1642-1654.

Furie, B., and Furie, B.C. (2005). Thrombus formation in vivo. J. Clin. Invest. 115, 3355-3362.

Gailani, D., and Broze, G.J.J. (1991). Factor XI activation in a revised model of blood coagulation. Science 253, 909-912.

Gailani, D., Bane, C.E., and Gruber, A. (2015). Factor XI and contact activation as targets for antithrombotic therapy. J. Thromb. Haemost. 13, 1383-1395.

Ganguly, P. (1974). Binding of thrombin to human platelets. Nature 247, 306-307.

Gao, F., Shen, H., Wang, Z.J., Yang, S.W., Liu, X.L., and Zhou, Y.J. (2015). Risk and benefit of direct oral anticoagulants or PAR-1 antagonists in addition to antiplatelet therapy in patients with acute coronary syndrome. Thromb. Res. 136, 243-249.

Geddings, J.E., and Mackman, N. (2014). New players in haemostasis and thrombosis. Thromb. Haemost. 111, 570-4

Geng, Y., Verhamme, I.M., Smith, S.A., Cheng, Q., Sun, M., Sheehan, J.P., Morrissey, J.H., and Gailani, D. (2013). Factor XI anion-binding sites are required for productive interactions with polyphosphate. J. Thromb. Haemost. 11, 2020-2028.

Golebiewska, E.M., and Poole, A.W. (2013). Secrets of platelet exocytosis - what do we really know about platelet secretion mechanisms? Br. J. Haematol. 165, 204-216.

Golebiewska, E.M., and Poole, A.W. (2015). Platelet secretion: From haemostasis to wound healing and beyond. Blood Rev. 29, 153-162.

de Graaf, J.C., Banga, J.D., Moncada, S., Palmer, R.M., de Groot, P.G., and Sixma, J.J. (1992). Nitric oxide functions as an inhibitor of platelet adhesion under flow conditions. Circulation 85, 2284-2290. 
Gresele, P., Harrison, P., Bury, L., Falcinelli, E., Gachet, C., Hayward, C.P., Kenny, D., Mezzano, D., Mumford, A.D., Nugent, D., et al. (2014). Diagnosis of suspected inherited platelet function disorders: results of a worldwide survey. J. Thromb. Haemost. 12, 1562-1569.

Grunkemeier, J.M., Tsai, W.B., and Horbett, T.A. (1998). Hemocompatibility of treated polystyrene substrates: contact activation, platelet adhesion, and procoagulant activity of adherent platelets. J. Biomed. Mater. Res. 41, 657-670.

Gunay-Aygun, M., Huizing, M., and Gahl, W.A. (2004). Molecular defects that affect platelet dense granules. Semin. Thromb. Hemost. 30, 537-547.

Hagedorn, I., Schmidbauer, S., Pleines, I., Kleinschnitz, C., Kronthaler, U., Stoll, G., Dickneite, G., and Nieswandt, B. (2010). Factor XIIa inhibitor recombinant human albumin Infestin-4 abolishes occlusive arterial thrombus formation without affecting bleeding. Circulation 121, 1510-1517.

Hantgan, R.R., Nichols, W.L., and Ruggeri, Z.M. (1990). von Willebrand factor competes with fibrin for occupancy of GPIIb:IIIa on thrombin-stimulated platelets. Blood 75, 889-894.

Harker, L.A., and Finch, C.A. (1969). Thrombokinetics in man. J. Clin. Invest. 48, 963-974.

Harker, L.A., Roskos, L.K., Marzec, U.M., Carter, R.A., Cherry, J.K., Sundell, B., Cheung, E.N., Terry, D., and Sheridan, W. (2000). Effects of megakaryocyte growth and development factor on platelet production, platelet life span, and platelet function in healthy human volunteers. Blood 95, 2514 LP-2522.

Heemskerk, J.W., Feijge, M.A., Henneman, L., Rosing, J., and Hemker, H.C. (1997). The Ca2+-mobilizing potency of alpha-thrombin and thrombin-receptor-activating peptide on human platelets -- concentration and time effects of thrombin-induced Ca2+ signaling. Eur. J. Biochem. 249, 547-555.

Heemskerk, J.W.M., Mattheij, N.J.A., and Cosemans, J.M.E.M. (2013). Platelet-based coagulation: different populations, different functions. J. Thromb. Haemost. 11, 2-16.

Heijnen, H.F., Schiel, A.E., Fijnheer, R., Geuze, H.J., and Sixma, J.J. (1999). Activated platelets release two types of membrane vesicles: microvesicles by surface shedding and exosomes derived from exocytosis of multivesicular bodies and alpha-granules. Blood 94, 3791-3799.

Hoffman, M., and Monroe, D.M. 3rd (2001). A cell-based model of hemostasis. Thromb. Haemost. 85, 958-965. 
Italiano, J.E.J., Lecine, P., Shivdasani, R.A., and Hartwig, J.H. (1999). Blood platelets are assembled principally at the ends of proplatelet processes produced by differentiated megakaryocytes. J. Cell Biol. 147, 1299-1312.

Iwanaga, S. (1993). The limulus clotting reaction. Curr. Opin. Immunol. 5, 74-82.

Jacques, S.L., and Kuliopulos, A. (2003). Protease-activated receptor-4 uses dual prolines and an anionic retention motif for thrombin recognition and cleavage. Biochem. J. 376, 733-740.

Jamieson, G.A., and Okumura, T. (1978). Reduced thrombin binding and aggregation in Bernard-Soulier platelets. J Clin Invest 61, 861-864.

Jonnalagadda, D., Izu, L.T., and Whiteheart, S.W. (2012). Platelet secretion is kinetically heterogeneous in an agonist-responsive manner. Blood 120 , 5209-5216.

Kahn, M.L., Zheng, Y.-W., Huang, W., Bigornia, V., Zeng, D., Moff, S., Farese, R. V, Tam, C., and Coughlin, S.R. (1998). A dual thrombin receptor system for platelet activation. Nature 394, 690-694.

van der Kamp, K.W., and van Oeveren, W. (1994). Factor XII fragment and kallikrein generation in plasma during incubation with biomaterials. J. Biomed. Mater. Res. 28, 349-352.

Kaushansky, K., Broudy, V.C., Lin, N., Jorgensen, M.J., McCarty, J., Fox, N., Zucker-Franklin, D., and Lofton-Day, C. (1995). Thrombopoietin, the Mp1 ligand, is essential for full megakaryocyte development. Proc. Natl. Acad. Sci. U. S. A. 92, 3234-3238.

Kelley, M.J., Jawien, W., Ortel, T.L., and Korczak, J.F. (2000). Mutation of MYH9, encoding non-muscle myosin heavy chain A, in May-Hegglin anomaly. Nat. Genet. 26, 106-108.

Kenne, E., Nickel, K.F., Long, a. T., Fuchs, T. a., Stavrou, E.X., Stahl, F.R., and Renné, T. (2015). Factor XII: a novel target for safe prevention of thrombosis and inflammation. J. Intern. Med. 278, 571-85.

Keuren, J.F.W., Wielders, S.J.H., Ulrichts, H., Hackeng, T., Heemskerk, J.W.M., Deckmyn, H., Bevers, E.M., and Lindhout, T. (2005). Synergistic effect of thrombin on collagen-induced platelet procoagulant activity is mediated through protease-activated receptor-1. Arterioscler. Thromb. Vasc. Biol. 25, 1499-1505.

Khorana, A.A., Francis, C.W., Menzies, K.E., Wang, J.-G., Hyrien, O., Hathcock, J., Mackman, N., and Taubman, M.B. (2008). Plasma tissue factor 
may be predictive of venous thromboembolism in pancreatic cancer. J. Thromb. Haemost. 6, 1983-1985.

Kleinschnitz, C., Stoll, G., Bendszus, M., Schuh, K., Pauer, H.-U., Burfeind, P., Renne, C., Gailani, D., Nieswandt, B., and Renne, T. (2006). Targeting coagulation factor XII provides protection from pathological thrombosis in cerebral ischemia without interfering with hemostasis. J. Exp. Med. 203, 513-518.

Kornberg, A. (1995). Inorganic polyphosphate: toward making a forgotten polymer unforgettable. J. Bacteriol. 177, 491-496.

Koseoglu, S., and Flaumenhaft, R. (2013). Advances in platelet granule biology. Curr. Opin. Hematol. 2O, 464-471.

Koster, T., Rosendaal, F.R., Briet, E., and Vandenbroucke, J.P. (1994). John Hageman's factor and deep-vein thrombosis: Leiden thrombophilia Study. Br. J. Haematol. 87, 422-424.

Krem, M.M., and Di Cera, E. (2001). Molecular markers of serine protease evolution. EMBO J. 20, 3036-3045.

Krem, M.M., and Di Cera, E. (2002). Evolution of enzyme cascades from embryonic development to blood coagulation. Trends Biochem. Sci. 27, 67-74.

Kretz, C.A., Stafford, A.R., Fredenburgh, J.C., and Weitz, J.I. (2006). HD1, a Thrombin-directed Aptamer, Binds Exosite 1 on Prothrombin with High Affinity and Inhibits Its Activation by Prothrombinase. J. Biol. Chem. 281, 37477-37485.

Kumar, S., and Hedges, S.B. (1998). A molecular timescale for vertebrate evolution. Nature 392, 917-920.

de la Fuente, M., Noble, D.N., Verma, S., and Nieman, M.T. (2012). Mapping human protease-activated receptor 4 (PAR4) homodimer interface to transmembrane helix 4. J. Biol. Chem. 287, 10414-10423.

Lancé, M.D. (2015). A general review of major global coagulation assays: thrombelastography, thrombin generation test and clot waveform analysis. Thromb. J. 13, 1.

Leger, A.J., Jacques, S.L., Badar, J., Kaneider, N.C., Derian, C.K., Andrade-Gordon, P., Covic, L., and Kuliopulos, A. (2006). Blocking the Protease-Activated Receptor 1-4 Heterodimer in Platelet-Mediated Thrombosis. Circulation 113, 1244-1254. 
Levin, J. (2013). Chapter 1 - The Evolution of Mammalian Platelets. In Platelets (Third Edition), (Academic Press), pp. 3-25.

Lhermusier, T., Chap, H., and Payrastre, B. (2011). Platelet membrane phospholipid asymmetry: from the characterization of a scramblase activity to the identification of an essential protein mutated in Scott syndrome. J. Thromb. Haemost. 9, 1883-1891.

Li, W., Johnson, D.J.D., Esmon, C.T., and Huntington, J. a (2004). Structure of the antithrombin-thrombin-heparin ternary complex reveals the antithrombotic mechanism of heparin. Nat. Struct. Mol. Biol. 11, 857-862.

Li, W., Johnson, D.J.D., Adams, T.E., Pozzi, N., De Filippis, V., and Huntington, J.A. (2010a). Thrombin Inhibition by Serpins Disrupts Exosite II. J. Biol. Chem. 285, 38621-38629.

Li, Z., Delaney, M.K., O'Brien, K. a, and Du, X. (2010b). Signaling during platelet adhesion and activation. Arterioscler. Thromb. Vasc. Biol. 30, 2341-2349.

Liou, J., Kim, M.L., Heo, W. Do, Jones, J.T., Myers, J.W., Ferrell, J.E.J., and Meyer, T. (2005). STIM is a Ca2+ sensor essential for Ca2+-store-depletion-triggered Ca2+ influx. Curr. Biol. 15, 1235-1241.

Lorand, L. (2001). Factor XIII: structure, activation, and interactions with fibrinogen and fibrin. Ann. N. Y. Acad. Sci. 936, 291-311.

Ma, L., Perini, R., McKnight, W., Dicay, M., Klein, A., Hollenberg, M.D., and Wallace, J.L. (2005). Proteinase-activated receptors 1 and 4 counter-regulate endostatin and VEGF release from human platelets. Proc Natl Acad Sci U S A 102, 216-220.

Maas, C., Govers-Riemslag, J.W.P., Bouma, B., Schiks, B., Hazenberg, B.P.C., Lokhorst, H.M., Hammarstrom, P., ten Cate, H., de Groot, P.G., Bouma, B.N., et al. (2008). Misfolded proteins activate factor XII in humans, leading to kallikrein formation without initiating coagulation. J. Clin. Invest. 118, 3208-3218.

Macfarlane, R.G. (1964). An enzyme cascade in the blood clotting mechanism, and its function as a biological amplifier. Nature 202, 498-499.

Madaras, F., Parkin, J.D., and Castaldi, P.A. (1979). Coagulation in the sand crab (Ovalipes bipustulatus). Thromb. Haemost. 42, 734-742.

Mann, K.G., Brummel, K., Butenas, S., and Article, R. (2003). What is all that thrombin for ? J. Thromb. Haemost. 1, 1504-1514. 
Marcus, A.J., Safier, L.B., Hajjar, K.A., Ullman, H.L., Islam, N., Broekman, M.J., and Eiroa, A.M. (1991). Inhibition of platelet function by an aspirin-insensitive endothelial cell ADPase. Thromboregulation by endothelial cells. J. Clin. Invest. 88, 1690-1696.

Marjoram, R.J., Voss, B., Pan, Y., Dickeson, S.K., Zutter, M.M., Hamm, H.E., and Santoro, S.A. (2009). Suboptimal Activation of Protease-activated Receptors Enhances $\alpha_{2} \beta 1$ Integrin-mediated Platelet Adhesion to Collagen. J. Biol. Chem. 284, 34640-34647.

Mazharian, A., Roger, S., Berrou, E., Adam, F., Kauskot, A., Nurden, P., Jandrot-Perrus, M., and Bryckaert, M. (2007). Protease-activating Receptor-4 Induces Full Platelet Spreading on a Fibrinogen Matrix. J. Biol. Chem. $282,5478-5487$.

van der Meijden, P.E.J., Feijge, M.A.H., Giesen, P.L.A., Huijberts, M., van Raak, L.P.M., and Heemskerk, J.W.M. (2005). Platelet P2Y12 receptors enhance signalling towards procoagulant activity and thrombin generation. A study with healthy subjects and patients at thrombotic risk. Thromb. Haemost. 93, 1128-1136.

van der Meijden, P.E.J., Munnix, I.C.A., Auger, J.M., Govers-Riemslag, J.W.P., Cosemans, J.M.E.M., Kuijpers, M.J.E., Spronk, H.M., Watson, S.P., Renne, T., and Heemskerk, J.W.M. (2009). Dual role of collagen in factor XII-dependent thrombus formation. Blood 114, 881-890.

Michelson, A. (1996). Flow cytometry : a clinical test of platelet function. Blood 87, 4925-4936.

Michelson, A.D. (1994). Platelet activation by thrombin can be directly measured in whole blood through the use of the peptide GPRP and flow cytometry: methods and clinical applications. Blood Coagul. Fibrinolysis 5 , 121-31.

Miyazaki, Y., Nomura, S., Miyake, T., Kagawa, H., Kitada, C., Taniguchi, H., Komiyama, Y., Fujimura, Y., Ikeda, Y., and Fukuhara, S. (1996). High shear stress can initiate both platelet aggregation and shedding of procoagulant containing microparticles. Blood 88, 3456-3464.

Mohammed, S.F., Whitworth, C., Chuang, H.Y., Lundblad, R.L., and Mason, R.G. (1976). Multiple active forms of thrombin: binding to platelets and effects on platelet function. Proc. Natl. Acad. Sci. U. S. A. 73, 1660-1663.

Moncada, S., Gryglewski, R., Bunting, S., and Vane, J.R. (1976). An enzyme isolated from arteries transforms prostaglandin endoperoxides to an unstable substance that inhibits platelet aggregation. Nature 263, 663-665. 
Monroe, D.M., and Hoffman, M. (2006). What does it take to make the perfect clot? Arterioscler. Thromb. Vasc. Biol. 26, 41-48.

Munnix, I.C.A., Kuijpers, M.J.E., Auger, J., Thomassen, C.M.L.G.D., Panizzi, P., Van Zandvoort, M.A.M., Rosing, J., Bock, P.E., Watson, S.P., and Heemskerk, J.W.M. (2007). Segregation of platelet aggregatory and procoagulant microdomains in thrombus formation: Regulation by transient integrin activation. Arterioscler. Thromb. Vasc. Biol. 27, 2484-2490.

Müller, F., Mutch, N., Schenk, W., Smith, S., E, L., Spronk, H., Schmidbauer, S., Gahl, W., Morrissey, J., and Renné, T. (2009). Platelet polyphosphates are proinflammatory and procoagulant mediators in vivo. Cell 139, $1143-1156$.

Nakanishi-Matsui, M., Zheng, Y.-W., Sulciner, D.J., Weiss, E.J., Ludeman, M.J., and Coughlin, S.R. (2000). PAR3 is a cofactor for PAR4 activation by thrombin. Nature 404, 609-613.

Nickel, K.F., Spronk, H.M., Mutch, N.J., Renné, T., Renne, T., Harrison, J.S., Rameshwar, P., Chang, V., and Bandari, P. (2013). Time-dependent degradation and tissue factor addition mask the ability of platelet polyphosphates in activating factor XII-mediated coagulation. Blood 122, 3847-3849.

Nurden, A.T., and Nurden, P. (2007). The gray platelet syndrome: clinical spectrum of the disease. Blood Rev. 21, 21-36.

van Oeveren, W., Haan, J., Lagerman, P., and Schoen, P. (2002). Comparison of coagulation activity tests in vitro for selected biomaterials. Artif. Organs 26, 506-511.

Okumura, T., and Jamieson, G.A. (1976). Platelet glycocalicin: a single receptor for platelet aggregation induced by thrombin or ristocetin. Thromb Res 8, 701-706.

Oliver, J.A., Monroe, D.M., Roberts, H.R., and Hoffman, M. (1999). Thrombin activates factor XI on activated platelets in the absence of factor XII. Arterioscler. Thromb. Vasc. Biol. 19, 170-177.

Oliver, J.A., Monroe, D.M., Church, F.C., Roberts, H.R., and Hoffman, M. (2002). Activated protein C cleaves factor Va more efficiently on endothelium than on platelet surfaces. Blood 100, 539-546.

Ollivier, V., Wang, J., Manly, D., Machlus, K.R., Wolberg, A.S., Jandrot-Perrus, M., and Mackman, N. (2010). Detection of endogenous tissue factor levels in plasma using the calibrated automated thrombogram assay. Thromb. Res. 125, 90-96. 
Olson, S.T., Bjork, I., and Shore, J.D. (1993). Kinetic characterization of heparin-catalyzed and uncatalyzed inhibition of blood coagulation proteinases by antithrombin. Methods Enzymol. 222, 525-559.

Ono, A., Westein, E., Hsiao, S., Nesbitt, W.S., Hamilton, J.R., Schoenwaelder, S.M., and Jackson, S.P. (2008). Identification of a fibrin-independent platelet contractile mechanism regulating primary hemostasis and thrombus growth. Blood 112, 90-99.

Osterud, B., and Rapaport, S.I. (1977). Activation of factor IX by the reaction product of tissue factor and factor VII: additional pathway for initiating blood coagulation. Proc. Natl. Acad. Sci. U. S. A. 74, 5260-5264.

Patel, S.R., Richardson, J.L., Schulze, H., Kahle, E., Galjart, N., Drabek, K., Shivdasani, R.A., Hartwig, J.H., and Italiano, J.E.J. (2005). Differential roles of microtubule assembly and sliding in proplatelet formation by megakaryocytes. Blood 106, 4076-4085.

Petrera, N.S., Stafford, A.R., Leslie, B.A., Kretz, C.A., Fredenburgh, J.C., and Weitz, J.I. (2009). Long range communication between exosites 1 and 2 modulates thrombin function. J. Biol. Chem. 284, 25620-25629.

Pineda, A.O., Chen, Z.-W., Marino, F., Mathews, F.S., Mosesson, M.W., and Di Cera, E. (2007). Crystal structure of thrombin in complex with fibrinogen gamma' peptide. Biophys. Chem. 125, 556-559.

Podolnikova, N.P., Yakovlev, S., Yakubenko, V.P., Wang, X., Gorkun, O. V, and Ugarova, T.P. (2014). The interaction of integrin alphaIIbbeta3 with fibrin occurs through multiple binding sites in the alphaIIb beta-propeller domain. J. Biol. Chem. 289, 2371-2383.

Ramström, S., Rånby, M., and Lindahl, T.L. (2003). Platelet phosphatidylserine exposure and procoagulant activity in clotting whole blood - different effects of collagen,TRAP and calcium ionophore A23187. Thromb. Haemost. 89, 132-141.

Rasmussen, U.B., Vouret-Craviari, V., Jallat, S., Schlesinger, Y., Pages, G., Pavirani, A., Lecocq, J.P., Pouyssegur, J., and Van Obberghen-Schilling, E. (1991). cDNA cloning and expression of a hamster alpha-thrombin receptor coupled to Ca2+ mobilization. FEBS Lett. 288, 123-128.

Ratnoff, O.D. (1980). A quarter century with Mr. Hageman. Thromb. Haemost. 43, 95-98.

Ratnoff, O.D. (1987). The evolution of hemostatic mechanisms. Perspect. Biol. Med. 31, 4-33. 
Ravindranath, M.H. (1980). Haemocytes in haemolymph coagulation of arthropods. Biol. Rev. 55, 139-170.

Renne, T., Pozgajova, M., Gruner, S., Schuh, K., Pauer, H.-U., Burfeind, P., Gailani, D., and Nieswandt, B. (2005). Defective thrombus formation in mice lacking coagulation factor XII. J. Exp. Med. 202, 271-281.

Renné, T., Schmaier, A.H., Nickel, K.F., Blombäck, M., and Maas, C. (2012). In vivo roles of factor XII. Blood 120, 4296-4303.

Reutelingsperger, C.P., Kop, J.M., Hornstra, G., and Hemker, H.C. (1988). Purification and characterization of a novel protein from bovine aorta that inhibits coagulation. Inhibition of the phospholipid-dependent factor-Xa-catalyzed prothrombin activation, through a high-affinity binding of the anticoagulant to the phospholipid. Eur. J. Biochem. 173, 171-178.

Revenko, A.S., Gao, D., Crosby, J.R., Bhattacharjee, G., Zhao, C., May, C., Gailani, D., Monia, B.P., and MacLeod, A.R. (2011). Selective depletion of plasma prekallikrein or coagulation factor XII inhibits thrombosis in mice without increased risk of bleeding. Blood 118, 5302-5311.

Roberts, H.R. (2003). Oscar Ratnoff: his contributions to the golden era of coagulation research. Br. J. Haematol. 122, 180-192.

Roos, J., DiGregorio, P.J., Yeromin, A. V, Ohlsen, K., Lioudyno, M., Zhang, S., Safrina, O., Kozak, J.A., Wagner, S.L., Cahalan, M.D., et al. (2005). STIM1, an essential and conserved component of store-operated Ca2+ channel function. J. Cell Biol. 169, 435-445.

Ruggeri, Z.M., and Mendolicchio, G.L. (2007). Adhesion Mechanisms in Platelet Function. Circ Res 10o, 1673-1685.

Ruggeri, Z.M., Zarpellon, A., Roberts, J.R., Mc Clintock, R. a, Jing, H., and Mendolicchio, G.L. (2010). Unravelling the mechanism and significance of thrombin binding to platelet glycoprotein Ib. Thromb. Haemost. 104, 894-902.

Ruiz, F.A., Lea, C.R., Oldfield, E., and Docampo, R. (2004). Human platelet dense granules contain polyphosphate and are similar to acidocalcisomes of bacteria and unicellular eukaryotes. J. Biol. Chem. 279, 44250-44257.

Sambrano, G.R., Weiss, E.J., Zheng, Y.-W., Huang, W., and Coughlin, S.R. (2001). Role of thrombin signalling in platelets in haemostasis and thrombosis. Nature 413, 74-78.

Samuel, M., Pixley, R.A., Villanueva, M.A., Colman, R.W., and Villanueva, G.B. (1992). Human factor XII (Hageman factor) autoactivation by dextran 
sulfate. Circular dichroism, fluorescence, and ultraviolet difference spectroscopic studies. J. Biol. Chem. 267, 19691-19697.

Saunders, D.C. (1966). Differential Blood Cell Counts of 121 Species of Marine Fishes of Puerto Rico. Trans. Am. Microsc. Soc. 85, 427-449.

Savage, B., Saldivar, E., and Ruggeri, Z.M. (1996). Initiation of platelet adhesion by arrest onto fibrinogen or translocation on von Willebrand factor. Cell 84, 289-297.

Savage, B., Almus-Jacobs, F., and Ruggeri, Z.M. (1998). Specific synergy of multiple substrate-receptor interactions in platelet thrombus formation under flow. Cell 94, 657-666.

Scheraga, H.A. (2004). The thrombin-fibrinogen interaction. Biophys. Chem. 112, 117-130.

Schmaier, A.A., Stalker, T.J., Runge, J.J., Lee, D., Nagaswami, C., Mericko, P., Chen, M., Cliché, S., Gariépy, C., Brass, L.F., et al. (2012). Occlusive thrombi arise in mammals but not birds in response to arterial injury: evolutionary insight into human cardiovascular disease Occlusive thrombi arise in mammals but not birds in response to arterial injury : evolutionary insight into human card. 118, 3661-3669.

Segers, K., Dahlback, B., Bock, P.E., Tans, G., Rosing, J., and Nicolaes, G.A.F. (2007). The role of thrombin exosites I and II in the activation of human coagulation factor V. J. Biol. Chem. 282, 33915-33924.

Shapiro, M.J., Weiss, E.J., Faruqi, T.R., and Coughlin, S.R. (2000). Protease-activated receptors 1 and 4 are shut off with distinct kinetics after activation by thrombin. J. Biol. Chem. 275, 25216-25221.

Shattil, S.J., Hoxie, J.A., Cunningham, M., and Brass, L.F. (1985). Changes in the platelet membrane glycoprotein IIb.IIIa complex during platelet activation. J. Biol. Chem. 260, 11107-11114.

Shattil, S.J., Cunningham, M., and Hoxie, J.A. (1987). Detection of activated platelets in whole blood using activation- dependent monoclonal antibodies and flow cytometry. Blood 70, $307 \mathrm{LP}-315$.

Shu, D.-G., Luo, H.-L., Conway Morris, S., Zhang, X.-L., Hu, S.-X., Chen, L.-Z., Han, J., Zhu, M., and Li, Y. (1999). Lower Cambrian vertebrates from south China. Nature 402, 42-46.

Smith, S.A., Mutch, N.J., Baskar, D., Rohloff, P., Docampo, R., and Morrissey, J.H. (2006). Polyphosphate modulates blood coagulation and fibrinolysis. Proc. Natl. Acad. Sci. U. S. A. 103, 903-908. 
Soslau, G., Class, R., Morgan, D.A., Foster, C., Lord, S.T., Marchese, P., and Ruggeri, Z.M. (2001). Unique pathway of thrombin-induced platelet aggregation mediated by glycoprotein Ib. J Biol Chem 276, 21173-21183.

Soslau, G., Goldenberg, S.J., Class, R., and Jameson, B. (2004). Differential activation and inhibition of human platelet thrombin receptors by structurally distinct alpha-, beta- and gamma-thrombin. Platelets 15, 155-166.

Stalker, T.J., Traxler, E. a, Wu, J., Wannemacher, K.M., Cermignano, S.L., Voronov, R., Diamond, S.L., and Brass, L.F. (2013). Hierarchical organization in the hemostatic response and its relationship to the platelet signaling network. Blood 121, 1875-1886.

Stalker, T.J., Welsh, J.D., Tomaiuolo, M., Wu, J., Colace, T. V., Diamond, S.L., and Brass, L.F. (2014). A systems approach to hemostasis: 3. Thrombus consolidation regulates intrathrombus solute transport and local thrombin activity. Blood 124, 1824-1831.

Stefanini, L., Roden, R.C., and Bergmeier, W. (2009). CalDAG-GEFI is at the nexus of calcium-dependent platelet activation. Blood 114, 2506-2514.

Suh, T.T., Holmback, K., Jensen, N.J., Daugherty, C.C., Small, K., Simon, D.I., Potter, S., and Degen, J.L. (1995). Resolution of spontaneous bleeding events but failure of pregnancy in fibrinogen-deficient mice. Genes Dev. 9, 2020-2033.

Sun, W.Y., Witte, D.P., Degen, J.L., Colbert, M.C., Burkart, M.C., Holmback, K., Xiao, Q., Bugge, T.H., and Degen, S.J. (1998). Prothrombin deficiency results in embryonic and neonatal lethality in mice. Proc. Natl. Acad. Sci. U. S. A. 95, 7597-7602.

Svoboda, O., and Bartunek, P. (2015). Origins of the Vertebrate Erythro/ Megakaryocytic System. Biomed Res. Int. 2015, 1-10.

Takahashi, A., Camacho, P., Lechleiter, J.D., and Herman, B. (1999). Measurement of intracellular calcium. Physiol. Rev. 79, 1089-1125.

Tam, S.W., and Detwiler, T.C. (1978). Binding of thrombin to human platelet plasma membranes. Biochim. Biophys. Acta 543, 194-201.

Tardy-Poncet, B., Piot, M., Chapelle, C., France, G., Campos, L., Garraud, O., Decousus, H., Mismetti, P., and Tardy, B. (2009). Thrombin generation and heparin-induced thrombocytopenia. J. Thromb. Haemost. 7, 1474-1481.

Tesselaar, M.E.T., Romijn, F.P.H.T.M., Van Der Linden, I.K., Prins, F.A., Bertina, R.M., and Osanto, S. (2007). Microparticle-associated tissue factor activity: a link between cancer and thrombosis? J. Thromb. Haemost. 5, $520-527$. 
Thiagarajan, P., and Tait, J.F. (1990). Binding of annexin V/placental anticoagulant protein I to platelets. Evidence for phosphatidylserine exposure in the procoagulant response of activated platelets. J. Biol. Chem. 265, 17420-17423.

Tollefsen, D.M., and Majerus, P.W. (1976). Evidence for a single class of thrombin-binding sites of human platelets. Biochemistry 15, 2144-2149.

Tollefsen, D.M., Feagler, J.R., and Majerus, P.W. (1974). The binding of thrombin to the surface of human platelets. J. Biol. Chem. 249, 2646-2651.

Tutwiler, V., Litvinov, R.I., Lozhkin, A.P., Peshkova, A.D., Lebedeva, T., Ataullakhanov, F.I., Spiller, K.L., Cines, D.B., and Weisel, J.W. (2016). Kinetics and mechanics of clot contraction are governed by the molecular and cellular composition of the blood. 127, 149-160.

Tynngård, N., Lindahl, T.L., and Ramström, S. (2015). Assays of different aspects of haemostasis - what do they measure? Thromb. J. 13, 8.

Wagner, C.L., Mascelli, M.A., Neblock, D.S., Weisman, H.F., Coller, B.S., and Jordan, R.E. (1996). Analysis of GPIIb/IIIa receptor number by quantification of $7 \mathrm{E}_{3}$ binding to human platelets. Blood 88, 907-914.

Walsh, P.N. (2004). Platelet coagulation-protein interactions. Semin. Thromb. Hemost. 3O, 461-471.

Varga-Szabo, D., Braun, A., and Nieswandt, B. (2009). Calcium signaling in platelets. J. Thromb. Haemost. 7, 1057-1066.

Wegner, J., Ph, D., and Popovsky, M.A. (2010). Clinical utility of thromboelastography: one size does not fit all. Semin. Thromb. Hemost. 36, 699-706.

Welsh, J.D., Colace, T. V., Muthard, R.W., Stalker, T.J., Brass, L.F., and Diamond, S.L. (2012). Platelet-targeting sensor reveals thrombin gradients within blood clots forming in microfluidic assays and in mouse. J. Thromb. Haemost. 10, 2344-2353.

Welsh, J.D., Stalker, T.J., Voronov, R., Muthard, R.W., Tomaiuolo, M., Diamond, S.L., and Brass, L.F. (2014). A systems approach to hemostasis: 1. The interdependence of thrombus architecture and agonist movements in the gaps between platelets. Blood 124, 1808-1815.

Welsh, J.D., Muthard, R.W., Stalker, T.J., Taliaferro, J.P., Diamond, S.L., and Brass, L.F. (2016). A systems approach to hemostasis : 4 . How hemostatic thrombi limit the loss of plasma-borne molecules from the microvasculature. Blood 127, 1598-605 
Versteeg, H.H., Heemskerk, J.W.M., Levi, M., and Reitsma, P.H. (2013). New fundamentals in hemostasis. Physiol. Rev. 93, 327-358.

White, G.C., Lundblad, R.L., and Griffith, M.J. (1981). Structure-function relations in platelet-thrombin reactions. Inhibition of platelet-thrombin interactions by lysine modification. J. Biol. Chem. 256, 1763-1766.

Wijeyewickrema, L.C., Gardiner, E.E., Shen, Y., Berndt, M.C., and Andrews, R.K. (2007). Fractionation of snake venom metalloproteinases by metal ion affinity: A purified cobra metalloproteinase, Nk, from Naja kaouthia binds Ni2+-agarose. Toxicon 5O, 1064-1072.

Wolf, P. (1967). The nature and significance of platelet products in human plasma. Br. J. Haematol. 13, 269-288.

Wong, P.C., Watson, C., Bostwick, J., Banville, J., Wexler, R., Priestley, S., Marinier, A., Bouvier, M., Gordon, D., Schumacher, W., et al. (2016). Abstract 175: A Novel Orally-Active Small-Molecule Antagonist of the Platelet Protease-Activated Receptor-4, BMS-986120, Inhibits Arterial Thrombosis With Limited Impact on Hemostasis in Cynomolgus Monkeys. Stroke 47, A175-.

Vretenbrant, K., Ramstrom, S., Bjerke, M., Lindahl, T.L., Sardjono, C.T., Harbour, S.N., Yip, J.C., Paddock, C., Tridandapani, S., Newman, P.J., et al. (2007). Platelet activation via PAR4 is involved in the initiation of thrombin generationand in clot elasticity development. Thromb. Haemost. 97, 417-424.

Wright, J.H., and Minot, G.R. (1917). The viscous metamorphosis of the blood platelets. J. Exp. Med. 26, 395-409.

Vu, T.K., Wheaton, V.I., Hung, D.T., Charo, I., and Coughlin, S.R. (1991a). Domains specifying thrombin-receptor interaction. Nature. 353, 674-677.

Vu, T.K.H., Hung, D.T., Wheaton, V.I., and Coughlin, S.R. (1991b). Molecular cloning of a functional thrombin receptor reveals a novel proteolytic mechanism of receptor activation. Cell 64, 1057-1068.

Wu, C.-C., Hwang, T.-L., Liao, C.-H., Kuo, S.-C., Lee, F.-Y., Lee, C.-Y., and Teng, C.-M. (2002). Selective inhibition of protease-activated receptor 4-dependent platelet activation by YD-3. Thromb. Haemost. 87, 1026-1033.

Wu, C.-C., Wang, W.-Y., Wei, C.-K., and Teng, C.-M. (2011). Combined blockade of thrombin anion binding exosite-1 and PAR4 produces synergistic antiplatelet effect in human platelets. Thromb. Haemost. 105, 88-95. 
Wu, C.-C.C., Hwang, T.-L.L., Liao, C.-H.H., Kuo, S.-C.C., Lee, F.-Y.Y., and Teng, C.-M.M. (2003). The role of PAR4 in thrombin-induced thromboxane production in human platelets. Thromb. Haemost. 90, 299-308.

Xu, H., Bush, L.A., Pineda, A.O., Caccia, S., and Di Cera, E. (2005). Thrombomodulin changes the molecular surface of interaction and the rate of complex formation between thrombin and protein C. J. Biol. Chem. 280 , 7956-7961.

Xu, W.F., Andersen, H., Whitmore, T.E., Presnell, S.R., Yee, D.P., Ching, A., Gilbert, T., Davie, E.W., and Foster, D.C. (1998). Cloning and characterization of human protease-activated receptor 4. Proc. Natl. Acad. Sci. U. S. A. 95, 6642-6646.

Zakharova, N. V., Artemenko, E.O., Podoplelova, N.A., Sveshnikova, A.N., Demina, I.A., Ataullakhanov, F.I., and Panteleev, M.A. (2015). Platelet surface-associated activation and secretion-mediated inhibition of coagulation factor XII. PLoS One 1O, 1-20.

van der Zee, P.M., Biro, E., Ko, Y., de Winter, R.J., Hack, C.E., Sturk, A., and Nieuwland, R. (2006). P-selectin- and CD63-exposing platelet microparticles reflect platelet activation in peripheral arterial disease and myocardial infarction. Clin. Chem. 52, 657-664.

Zeerleder, S., Schloesser, M., Redondo, M., Wuillemin, W.A., Engel, W., Furlan, M., and Lammle, B. (1999). Reevaluation of the incidence of thromboembolic complications in congenital factor XII deficiency--a study on 73 subjects from 14 Swiss families. Thromb. Haemost. 82, 1240-1246.

Zhang, S.L., Yu, Y., Roos, J., Kozak, J.A., Deerinck, T.J., Ellisman, M.H., Stauderman, K.A., and Cahalan, M.D. (2005). STIM1 is a Ca2+ sensor that activates CRAC channels and migrates from the Ca2+ store to the plasma membrane. Nature 437, 902-905.

Zhu, S., Travers, R.J., Morrissey, J.H., and Diamond, S.L. (2015). FXIa and platelet polyphosphate as therapeutic targets during human blood clotting on collagen/tissue factor surfaces under flow. Blood 126, 1494-1503. 
Part III. Papers 



\section{Populärvetenskaplig sammanfattning på svenska}

\section{Studier av gränsytor mellan primär och sekundär hemostas}

Kroppens ca 40000 miljarder celler är beroende av en ständig leverans av tillräckliga mängder syre och näringsämnen via det blod som pumpas runt i våra kärl. Ett minutkort avbrott i detta flöde kan göra skillnaden mellan liv och död. Hemostasen, förmågan att stoppa blödningar, är därför livsviktig för alla flercelliga organismer med någon form av cirkulation. Eftersom organismer med en förbättrad hemostas har större chanser att överleva och ge upphov till nytt liv, har evolutionen över hundratals miljoner år lett till utvecklingen av alltmer sinnrika och komplicerade system för hemostas. Dessa system bygger på att cellfragment i form av trombocyter (blodplättar) och proteiner i form av koagulationsfaktorer som cirkulerar i blodet ständigt kommunicerar med celler i kärlväggen och snabbt upptäcker sår. När en skada har identifieras reagerar systemen blixtsnabbt och bygger upp ett slags "tvåkomponentlim" som i huvudsak utgörs av trombocyter och fibrin, i olika proportioner beroende på vilket sorts kärl som har skadats. Limmet täpper igen det hål som har bildats, exempelvis när man har skurit eller slagit sig.

Tyvärr kan olika ålders- och vällevnadsrelaterade sjukdomar störa den känsliga kommunikationen mellan kärlväggen och de olika komponenterna i hemostasen. Förändringar i kärlväggen eller blodflödet leder då till att de system som har satts på plats för att förhindra blödning aktiveras på fel plats och vid fel tidpunkt, vilket ger upphov till proppsjukdomar såsom hjärtinfarkt, stroke, djup ventrombos och lungemboli. Dessa sjukdomar utgör tillsammans den vanligaste dödsorsaken i världen. Mycket forskning har därför ägnats åt att förstå hur hemostasen fungerar och åt att utveckla läkemedel som kan påverka hemostasen vid olika sjukdomar.

Eftersom kroppens system för hemostas är oerhört komplexa, är det svårt att studera alla dess olika komponenter på samma gång. För att göra saker och ting enklare för sig, har forskare ofta valt att dela upp hemostasen i 
ett cellbaserat och ett proteinbaserat system, kallade primär och sekundär hemostas, och studera vart och ett av dessa system för sig. En nackdel med ett sådant reduktionistiskt grepp är att gränsytorna mellan systemen förblir outforskade.

I denna avhandling har jag istället valt att sätta fokus på hur de cellbaserade och proteinbaserade systemen för hemostas påverkar varandra. I mitt första delarbete har jag studerat hur trombin, det protein som omvandlar fibrinogen till fibrin, också påverkar den primära hemostasen genom att aktivera trombocyter via två olika receptorer, PAR1 och PAR4. Min studie visar att en funktionellt betydelsefull del av trombin kallad exosite II är oumbärlig för att aktivera PAR4, och att blockering av exosite II med olika substanser helt slår ut aktiveringen av PAR4. Ämnen som blockerar exosite II finns naturligt i kroppen, men kan också redan idag tillföras som mediciner. Min studie kan därför bidra till förståelsen av hur trombocytaktivering kan påverkas av såväl kroppsegna substanser som olika läkemedel.

I mitt andra och tredje delarbete har jag utforskat en anförd teori om att trombocyter själva kan aktivera de processer som leder fram till fibrinbildning genom att utsöndra molekyler som kallas polyfosfater. Mina studier visar att denna hypotes är felaktig, och att tidigare positiva resultat delvis kan förklaras av bristande kunskaper om hur trombocyterna och koagulationen samverkar.

I mitt fjärde delarbete har jag studerat en av de metoder som används för att mäta hur trombocyterna kan påverka och eventuellt även aktivera koagulationen genom att frisätta så kallade mikropartiklar. Min studie visar att en metod som har använts för att mäta detta fenomen kan ge vilseledande resultat, då den påverkas kraftigt av så kallad kontaktaktivering. Min slutsats är att man bör tillgripa särskilda åtgärder för att eliminera kontaktaktivering vid framtida studier inom området.

Sammanfattningsvis bidrar min avhandling med nya insikter i hur trombocyter och koagulationsfaktorer samverkar i ett komplext nätverk av aktiviteter för att identifiera och stoppa blödningar. Mina studier bidrar även med viktig kunskap om vilka metoder som kan användas för att utforska de delar av detta nätverk som inte inryms i det snäva begreppsparet primär och sekundär hemostas. 


\section{Tack!}

När jag skriver detta är klockan 23:55 natten innan avhandlingen ska lämnas in för tryck, så jag är ledsen om jag mitt i all förvirring begår något oförlåtligt fel och glömmer någon jag bara inte fick glömma. Ni är så många som har gett mig så mycket!

Tack...

...mina handledare Tomas och Lars för att ni har trott på mig och stöttat mig i alla turer ända sedan jag som jobbsökande läkarstudent träffade Tomas för första gången på Wayne's Coffee 2008. Ni har nästan alltid tid för en engagerad pratstund, oavsett klockslag och datum. Jag betraktar er som mina vänner och mentorer båda två och hoppas att vi ska kunna fortsätta jobba tillsammans länge än.

...min pappa Nils-Åke för att du väckte mitt intresse för naturvetenskap så tidigt det bara gick. Ditt enorma kunnande och ditt knivskarpa intellekt har varit en fantastisk källa till inspiration för mig!

...min älskade fru Ellen för att du finns där för mig hela tiden. Du är min bästa.

...min kära mamma Elisabeth för att du är den du är, min största förebild i livet.

...Kjersti, Maria, Kerstin, Daniel, Ankit, Sofia, Majid, Anna, Nahreen och alla ni andra på labbet för att ni är ett så skönt gäng att forska med.

...alla kollegor på hematologen för att ni har gett mig ett hem på US.

...min kloka dotter Martha för att du lär mig så mycket om livet.

...min son Elis för att du är så nyfiken och vetgirig. Jag älskar att prata med dig om trombocyter, blödningar, proppar och Pokémon. 